\title{
Legal Regulation of Employment Reference Practices
}

\author{
J. Hoult Verkerke $\dagger$
}

A lively debate has raged in recent years about how to regulate employment reference practices. According to the conventional account, employers refuse to provide candid references because they fear defamation liability and perceive only the most speculative benefits from exposing themselves to the risk of suit. ${ }^{1}$ As a result, almost everyone appears to agree that employers are getting too little information about prospective employees. ${ }^{2} \mathrm{Al}-$ though there is considerably less agreement about the proper response to this problem, a number of commentators have suggested reforming defamation law or imposing disclosure obligations on former employers. ${ }^{3}$ In this Article, I examine these and

$\dagger$ Professor of Law and Director, Program for Employment and Labor Law Studies, University of Virginia. Readers may direct email to ripv@virginia.edu. For helpful comments on earlier drafts, I am grateful to George Cohen, Matthew Finkin, Robert Scott, and workshop participants at the University of Pennsylvania Law School, the University of Virginia School of Law, and the University of Virginia Department of Economics. Ann Coyle and Christy Lillquist provided excellent research assistance. Thanks for financial support are due to the University of Virginia Law School Foundation and the Program for Employment and Labor Law Studies. I alone am responsible for any remaining errors.

2 See, for example, Bradley Saxton, Flaws in the Laws Governing Employment References: Problems of "Overdeterrence" and a Proposal for Reform, 13 Yale L \& Policy Rev 45, 51-53 (1995); Diane Arthur, Recruiting, Interviewing, Selecting \& Orienting New Employees 231 (Amacom 2d ed 1991); Robert D. Gatewood and Hubert S. Feild, Human Resource Selection 411-12 (Dryden 2d ed 1990); John B. Miner and Mary Green Miner, Personnel and Industrial Relations: A Managerial Approach 332 (Macmillan 4th ed 1985).

${ }^{2}$ See, for example, Saxton, 13 Yale L \& Policy Rev at 45-46 (cited in note 1); Society for Human Resource Management, Reference Checking Leaves Employers in the Dark, SHRM Survey Says (June 26, 1995) ("SHRM Survey") (reporting survey results indicating that more than 50 percent of employers find reference information that they receive on personality traits and violent or bizarre behavior of potential hires to be inadequate). See also David C. Martin and Kathryn M. Bartol, Potential Libel and Slander Issues Involving Discharged Employees, 13 Employee Rel L J 43, 44 (1987) (noting that employers are reluctant to give out information); Kyle E. Skopic, Comment, Potential Employer Liability for Employee References, 21 U Richmond L Rev 427, 452-53 (1987) (same).

3 See Saxton, 13 Yale L \& Policy Rev at 76-113 (cited in note 1) (proposing a slight expansion of the qualified privilege: imposition of a limited affirmative duty on employees to provide reference information, and shifting of litigation fees in some reference practice suits); Edward R. Horkan, Note, Contracting Around the Law of Defamation and Employment References, $79 \mathrm{Va} \mathrm{L} \mathrm{Rev} \mathrm{517,} \mathrm{536-47} \mathrm{(1993)} \mathrm{(arguing} \mathrm{for} \mathrm{enforcement} \mathrm{of} \mathrm{employ-}$ ment contracts that modify the qualified privilege); Janet Swerdlow, Note, Negligent Referral: A Potential Theory for Employer Liability, 64 S Cal L Rev 1645, 1667-71 (1991) (proposing the creation of a negligent referral tort); Deborah Daniloff, Note, Employer 
other possible regulatory responses to the c'earth of reference information. Contrary to the conventional wisdom, I conclude that defamation law functions reasonably well in its present form, that disclosure obligations might well produce more harm than good, and finally that the most promising legal reforms are those that focus on the problems associated with hiring for high-risk occupations. I also explore how the law might facilitate both preexisting and innovative market mechanisms for information sharing.

In order to make the informational problems of employers more concrete, consider the following only partly hypothetical story. ${ }^{4}$ An eighth-grade student alleges that her teacher made sexual advances and exposed himself to her during an afterschool session concerning her science fair project. The school's principal finds the allegations credible and threatens to discharge the teacher immediately unless he agrees to resign at the end of the school year. Rather than facing the stigma of a disciplinary discharge, the teacher decides to resign, and in exchange, the principal agrees not to mention the alleged sexual misconduct to prospective employers who inquire about his performance. Armed with a letter of reference recounting the laudatory information in his recent performance appraisals, the teacher quickly finds a position at another school, once again teaching eighth-grade science. Some months later, a student at the new school reports that the teacher sexually assaulted her. Had prospective employers known of the initial complaint of sexual misconduct, it is doubtful that the teacher would have found another similar position, and at least one student might have been spared the trauma of sexual

Defamation: Reasons and Remedies for Declining References and Chilled Communications in the Workplace, 40 Hastings L J 687, 713-22 (1989) (advocating the elimination of punitive damages and the use of an "enhanced" standard of negligence in place of the qualified privilege in employer defamation cases); John B. Lewis, Bruce L. Ottley, and Gregory V. Mersol, Defamation and the Workplace: A Survey of the Law and Proposals for Reform, 54 Mo L Rev 797, 854-62 (1989) (proposing to abolish the distinction between libel and slander; adopt uniform standards for recovery, malice, and publication; limit punitive damages; and abolish presumed damages); O. Lee Reed and Jan W. Henkel, Facilitating the Flow of Truthful Personnel Information: Some Needed Change in the Standard Required to Overcome the Qualified Privilege to Defame, 26 Am Bus L J 305, 320-23 (1988) (advocating the adoption of a knowing falsity standard for defamation in qualified privilege cases). See also Valerie L. Acoff, Comment, References Available on Request . . . Not! Employers Are Being Sued for Providing Employee Job References, 17 Am J Trial Advoc 755, 770-71 (1994) (suggesting that employers and former employees agree on a reference that is satisfactory to both).

4 The story adds some factual embellishments to the basic scenario described in Randi W. $v$ Muroc Joint Unified School District, 14 Cal 4th 1066, 929 P2d 582, 585-86 (1997), and Cohen $v$ Wales, 133 AD2d 94, 518 NYS2d 633, 633-34 (NY App Div 1987). 
abuse. A lack of candid reference information thus impedes employers' efforts to avoid such hiring mistakes.

An intuitively appealing response to this problem would be to impose on the former employer a duty to disclose. ${ }^{5}$ Another obvious possibility is to reform defamation law so as to reduce the threat of liability that employers face when they provide candid references. ${ }^{6}$ Although these are plausible policy options, prior commentators have seriously underestimated the difficulty of designing appropriate legal reforms. The framework that I develop in this Article highlights the unique problems associated with regulating information flows and reveals complex interactions among the various legal and economic forces that influence employment reference practices. Although this analysis leads me to conclude that aggressive legal reforms would be ill advised, the framework also identifies some specific circumstances in which more modest reforms might be productive.

I begin with the proposition that labor market efficiency depends to a great extent on matching workers' strengths and weaknesses to the jobs that they will perform. If, however, employers have inadequate information about prospective employees, they are unable to create good matches through prudent hiring and job assignment decisions. Nevertheless, after observing workers on the job for some time, employers acquire the relevant information. At this point, they can retain their most productive employees and discharge or lay off those who are the least productive. The resulting employee turnover allows terminated workers to search for another job that better matches their abilities. ${ }^{7}$ In this way, employee turnover promotes efficiency.

I argue, however, that employee turnover, in combination with imperfect and asymmetric information, can also cause three

3 See Saxton, 13 Yale L \& Policy Rev at 91-99 (cited in note 1); Swerdlow, Note, $64 \mathrm{~S}$ Cal L Rev at 1661 (cited in note 3).

6 See Saxton, 13 Yale L \& Policy Rev at 77-90 (cited in note 1); Lewis, Ottley, and Mersol, 54 Mo L Rev at 855-62 (cited in note 3); Reed and Henkel, 26 Am Bus L J at 32023 (cited in note 3 ).

" See, for example, C.J. McKenna, Uncertainty and the Labour Market: Recent Developments in Job-Search Theory 62-66 (Harvester 1985) (arguing that much of the turnover results from an inefficient match between employer and employee); Robert M. Feinberg, Theoretical Implications and Empirical Tests of the Job Search Theory 23-28 (Garland 1984) (noting that some unemployment may be efficient because former employees can search for jobs that better fit their economic value); Boyan Jovanovic, Job Matching and the Theory of Turnover 13-60 (Garland 1984) (presenting statistical model showing that both employers and new employees analyze the economic efficiency of their relationship and will decide whether to continue it after an initial period of time necessary to make that determination). As I discuss below, discharge can also deter misconduct, incapacitate unproductive workers, or signal employee productivity to the labor market. See Section II.B.2. 
significant inefficiencies. "Mismatching" can occur whenever employers have inadequate information about the characteristics of prospective employees. "Churning" results when employees, such as our lecherous science teacher, move from one position to another without improving the quality of the match between worker and job. Finally, "scarring" occurs when employers rely on labor market signals to refuse to hire workers who could be employed productively. ${ }^{8}$ The complex interactions among these labor market phenomena, coupled with the inherent difficulty of regulating information flows, ensure that first-best efficiency is unattainable. ${ }^{9}$

The economic framework that I develop suggests that the search for second-best solutions must confront an inevitable trade-off between the quantity and the quality of available information concerning employee productivity. It is easy to imagine regulatory measures that would encourage employers to provide more reference information or would deter them from providing falsely positive references. However, the inescapable trade-off between quantity and quality substantially weakens the case for these reforms. Thus, for example, defamation law allegedly deters employers from providing candid references but at the same time it creates a much needed incentive to take precautions against providing falsely negative references. Reforms that would relax current liability rules can be justified only if they would increase the available quantity of information about former employees sufficiently to compensate for the concomitant decline in quality. Similarly, a limited disclosure obligation might increase the supply of reference information, but the analysis of scarring demonstrates that partial disclosure may well be worse than no disclosure at all. Finally, the problem of falsely positive references has led some courts to consider creating a tort of wrongful referral.

Although economists recently have begun to theorize about similar problems, I am unaware of any prior theoretical discussion of employee churning and scarring. For recent work concerning asymmetric information in the labor market, see Chun Chang and Yijang Wang, Human Capital Investment Under Asymmetric Information: The Pigovian Conjecture Revisited, 14 J Labor Econ 505 (1996); Robert Gibbons and Lawrence F. Katz, Layoffs and Lemons, 9 J Labor Econ 351 (1991); Joan E. Ricarti Costa, Managerial Task Assignment and Promotions, 56 Econometrica 449 (1988); Bruce C. Greenwald, Adverse Selection in the Labour Market, 53 Rev Econ Studies 325 (1986); Michael Waldman, Job Assignments, Signalling, and Efficiency, 15 Rand J Econ 255 (1984). None of these authors considers the implications of his or her analysis for the legal regulation of employee turnover or employment reference practices.

9 In the analysis that follows, informational asymmetry is the only source of market failure or inefficiency. A first-best equilibrium thus is synonymous with a full-information equilibrium. First-best efficiency requires either that parties become fully informed or that they behave as if they possessed all relevant information. 
However, high enforcement costs, and a significant chance that the threat of wrongful referral liability would deter employers from providing any reference information at all, help to explain why so few courts have entertained this theory of liability.

The economic framework that I develop to examine employment reference practices thus makes me skeptical that aggressive legal reforms will improve labor market efficiency. The existing combination of defamation liability for falsely negative references and the conditional common interest privilege ${ }^{10}$ applicable to supplying reference information strikes an appropriate balance between quantity and quality concerns. Nevertheless, the special risks associated with some hiring mistakes suggest the need to consider other, more modest, regulatory reforms. Lawmakers thus might consider adopting targeted reporting and disclosure systems for certain high-risk occupations. More generally, courts and legislators could try to encourage market mechanisms that produce and disseminate reference information. By clarifying the legal effect of various forms of reference transactions, a well articulated regulatory scheme could aid the efforts of market participants to pursue innovative arrangements for information sharing.

My analysis of these issues unfolds in three main parts. Section I describes the nature of the problem and existing legal rules affecting the flow of information in the labor market. Section II develops a theoretical account of the interaction between employee turnover and employers' access to information about employee productivity. Section III applies this framework to the regulation of employment reference practices. The Conclusion summarizes the argument and explains how the analysis also may produce insights concerning other significant legal issues.

\section{THE LEGAL ENVIRONMENT}

Prospective employers use the information contained in employment references to make hiring and job assignment decisions and to determine how much training, supervision, and monitoring new employees will require. Thus, just as the school that hired the science teacher in our earlier example would have liked to have known about his prior sexual misconduct, so also do airlines try to identify pilots who have a history of substance abuse; trucking companies attempt to avoid hiring reckless drivers; and investment firms hope to screen out rogue brokers who have

${ }^{10}$ For a description of the conditional common interest privilege, see notes 22-26 and accompanying text. 
abused their clients' trust. ${ }^{11}$ In high-risk situations such as these, hiring mistakes can cause tragic social losses. The resulting employee misconduct also severely erodes an employer's business reputation and may produce ruinous liability judgments under the doctrines of respondeat superior and negligent hiring or retention. ${ }^{12}$ Even in less extreme circumstances, however, information about applicants' prior job performance is quite valuable. Employers hiring clerical employees, factory workers, middle managers, and academic administrators care deeply about the productivity, reliability, and adaptability of job applicants. Employment references thus have tremendous potential to assist all employers with the difficult task of assessing prospective employees. ${ }^{13}$

The legal rules applicable to employment reference practices affect both the quantity and the quality of information that employers receive. Prospective employers and regulators confront three analytically distinct problems: falsely negative references, an inadequate supply of reference information, and falsely positive references. In addition, legal rules affect the vitality of the market for reference information. Courts and legislatures have responded to these challenges with a diverse collection of regulatory measures.

\section{A. Falsely Negative References}

The common law's answer to the problem of falsely negative references is the tort of defamation. As applied to employment reference practices, defamation law holds employers liable for

"Regulatory agencies in transportation industries also have been active in efforts to identify high-risk individuals. In 1991, for example, the Federal Aviation Administration ("FAA") began a program aimed at matching the names of licensed pilots with records of alcohol-related traffic offenses. Two convictions for driving under the influence of alcohol could trigger FAA action leading to the revocation of a pilot's license. See Lawrence $L$. Knutson, NTSB Lauds FAA Effort to Identify Problem Drinkers Among Pilots, Associated Press (July 9, 1991).

${ }^{12}$ See, for example, Summers $v$ Cotton Trucking, 1996 WL 451124, 21 Trials Dig 2d 75 (reporting a $\$ 3,192,000$ award of compensatory and punitive damages by a California jury for a negligent retention claim); Ortega $v$ Ancira, 1996 WL 402776, 20 Trials Dig 2d 90 (reporting a $\$ 4,200,000$ award of general damages by a California jury for a negligent retention claim involving sexual molestation by a school teacher); Tallahassee Furniture Co $v$ Harrison, 583 S2d 744, 754 (Fla Dist Ct App 1991) (affirming a \$2,500,000 award of compensatory and punitive damages on a negligent hiring and retention claim); Plains Resources, Inc $v$ Gable, 253 Kan 580, 682 P2d 653, 663 (1984) (affirming award of $\$ 1,282,569$ in compensatory and punitive damages on negligent retention claim and under respondeat superior).

${ }^{13}$ See, for example, Gatewood and Feild, Human Resource Selection at 402 (cited in note 1); Miner and Miner, Personnel and Industrial Relations: $A$ Managerial Approach at 330 (cited in note 1). 
providing references that contain false and defamatory statements. ${ }^{14}$ A statement is defamatory if it tends to lower the subject in the esteem of others. ${ }^{15}$ Thus, the tort reaches not only negative factual assertions but also derogatory subjective judgments from which a listener might infer the existence of negative facts about someone. ${ }^{16}$

Courts impose defamation liability principally to deter employers from unjustly harming a former employee's chances for re-employment. ${ }^{17}$ In this sense, the tort closely resembles many other legal efforts to deter harmful conduct. Courts have acknowledged explicitly that employment references play an important and socially beneficial role in the labor market. ${ }^{18}$ Courts therefore would prefer not to deter false references at the cost of

1" See Restatement (Second) of Torts $\$ 558$ (1977); Lewis v Equitable Life Assurance Society of the United States, 361 NW2d 875, 882 (Minn Ct App 1985) (holding former employer liable for defamatory reference to prospective employer), affd in part, revd in part, 389 NW2d 876 (Minn 1986); Vinson v Linn-Mar Community School District, 360 NW2d 108, 117-18 (Iowa 1984) (affirming finding of liability for defamatory reference by former employer).

${ }^{15}$ See, for example, Zinda v Louisiana Pacific Corp, 149 Wis 2d 913, 440 NW2d 548, 552 (1989) (" $[C]$ ommunication is defamatory if it tends to harm the reputation of another so as to lower him in the estimation of the community or deter third persons from associating or dealing with him.") (citation omitted).

${ }^{16}$ See Sigal Construction Corp v Stanbury, 586 A2d 1204, 1209 (DC 1991) (discussing liability for defamatory facts inferred from statements of "opinion" in light of the Supreme Court's ruling in Milkovich v Lorain Journal Co, 497 US 1 (1990)). Although a number of courts have held that statements of opinion are not actionable, see Matthew W. Finkin, Privacy in Employment Law 92 (BNA 1995), almost all of these decisions predate Milkovich. Courts considering this issue in the wake of the Supreme Court's decision may well expand the scope of actionable statements to include many statements formerly considered nondefamatory "opinion."

${ }^{17}$ Of course, the tort of defamation also aims to protect a person's general reputation. As applied to employment references, however, the overriding concern is with prospects for re-employment. See, for example, Linafelt $v$ Bev, Inc, 662 S2d 986, 988 (Fla Dist Ct App 1995) (Prospective employer, who expressed willingness to hire plaintiff subject to an acceptable employment reference, did not hire him after being told that Linafelt had been discharged for violation of company policy and would never be considered for rehire.); Yandle v Mitchell Motors, Inc, 199 Ga App 211, 404 SE2d 313, 314 (1991) (A note in the former employee's personnel file describing the reason for termination as lack of sales effort and resultant low production was read to prospective employers.); Weissman $v$ Sri Lanka Curry House, Inc, 469 NW2d 471, 471 (Minn Ct App 1991) (Plaintiff sued former employer after a prospective employer was given a reference that stated that she was "unreliable," "dishonest," and had "walked out."); Ramsay v Mary Imogene Bassett Hospital, 158 AD2d 754, 551 NYS2d 342, 343 (NY App Div 1990) (Plaintiff discovered that his former employer had been giving negative references to prospective employers, which prevented him from securing a new job.).

${ }^{18}$ See Rimmer $v$ Colt Industries Operating Corp, 656 F2d 323, 328 (8th Cir 1981) (recognizing the value of regulating reference letters to both employers and employees); Hett $v$ Plotz, 20 Wis 2d 55, 121 NW2d 270, 273 (1963) (noting a public interest in conditionally privileging communications such as reference letters). See also Restatement (Second) of Torts $\$ 596$ ("The rule is based on the fact that one is entitled to learn from his associates what is being done in a manner in which he has an interest in common."). 
eliminating this useful activity altogether. Faced with the threat of defamation liability for false statements, however, a rational employer might well decide that the risk of liability outweighs the benefit of providing candid references. ${ }^{19}$ In short, the referring employer bears the risk of liability while the prospective employer reaps all of the benefits. ${ }^{20}$ Defamation liability could quite

${ }^{19}$ An important behavioral puzzle is why employers freely record and share information internally while being unwilling to disseminate the same information outside the company. In the overwhelming majority of jurisdictions, defamation doctrine draws no distinction whatsoever between internal publication and external publication of negative information. See Restatement (Second) of Torts § 577 comment e; Lund $v$ Chicago \& NW Transportation Co, 467 NW2d 366, 368 (Minn Ct App 1991) (holding that to be actionable "a statement must be communicated to someone other than the plaintiff"); Luttrell $v$ United Telephone System, Inc, 9 Kan App 2d 620, 683 P2d 1292, 1294 (1984), affd, 236 Kan 710, 695 P2d 1279 (1985) (refusing to grant greater freedom from defamation liability for internal communications than for external communications). One possibility is that this difference in behavior results from the fact that the returns an employer can expect from sharing information externally are negligible as compared to the benefit of internal communications. The process of making day-to-day management decisions about employees demands that employers share information internally. Moreover, because defending claims of unjust or discriminatory discharge requires employers to document a legitimate basis for their decisions, the potential benefit of gathering negative information about someone they plan to discharge is extremely high. However, the benefits that employers obtain by sharing this information with other employers are considerably less obvious. But see Ramona L. Paetzold and Steven L. Willborn, Employer (Ir)rationality and the Demise of Employment References, 30 Am Bus L J 123, 126 (1992) (discussing potential benefits employers may derive from establishing a policy of providing candid references).

However, there is another significant difference between internal and external dissemination of information about employees. When information is gathered and shared internally, it typically concerns incumbent employees. In contrast, external requests for information invariably concern either former employees or current employees who will soon leave their jobs. The risk that former employees will sue for defamation is substantially greater than the risk that incumbent employees will sue. See John J. Donohue, III and Peter Siegelman, The Changing Nature of Employment Discrimination Litigation, 43 Stan L Rev 983, 1015, 1031 (1991) (noting that most employment discrimination cases brought before the Equal Employment Opportunity Commission involve termination charges; few suits are brought by current employees). Indeed, defamation claims are seldomly pursued separately. The majority of litigated defamation claims appear to involve former employees and are brought in conjunction with another statutory, tort, or contract claim alleging wrongful discharge. See, for example, White $v$ General Motors Corp, 908 F2d 675, 679 (10th Cir 1990) (action for wrongful discharge, breach of contract, and slander); Linafelt, 662 S2d at 986 (former employee sued for unlawful discharge, defamation, breach of contract, and intentional interference with an advantageous business relationship). The greater propensity of discharged employees to pursue legal action against their former employer creates a dramatic difference in the litigation risk from sharing information internally about incumbents and the risk from sharing externally the same sort of information about former employees. Thus, a comparison of both the litigation risk and the expected benefits from collecting and sharing information about employees favors internal over external dissemination.

20 Ramona Paetzold and Steve Willborn have argued creatively that a policy of giving candid references tends to encourage more productive employees to apply because they know that a favorable reference will help them to obtain a new job if they need one. See Paetzold and Willborn, 30 Am Bus L J at 126 (cited in note 19) ("Reference-giving by an employer may also aid employees in self-selection. Productive employees will prefer to 
easily chill this socially beneficial activity, thus causing employers to provide an inadequate supply of reference information.

\section{B. Activity-Level Problems}

To address this activity-level or quantity problem, ${ }^{21}$ the common law has developed the conditional "common interest" privilege. ${ }^{22}$ Because former and prospective employers are deemed to have a common interest in information about job applicants, employers who provide references are immune from defamation liability unless plaintiffs can prove that they abused the privilege in some way. ${ }^{23}$ Plaintiffs most commonly assert that their former employer abused the privilege by knowingly or recklessly making false and defamatory statements to a prospective employer. ${ }^{24}$ Because employment references so often involve

work for an employer who issues references, whereas nonproductive employees will prefer to work for an employer who does not give out performance-related reference information. This self-selection mechanism will enable employers who give references to develop more productive workforces."). It may be unrealistic to assume that prospective employees have an interest in and information about the reference practices of their potential employer. See Section III.A and note 122 and accompanying text, discussing informational obstacles that prevent an employer from developing a reputation among employees for providing inaccurate references. In any case, many employers appear unconvinced that the benefits of candid reference-giving exceed its costs.

${ }^{21}$ In analyzing the effects of tort law, legal economists customarily distinguish between (1) the influence that the law has on actors' investments in precautions and (2) its related "activity-level" effect on the extent to which actors engage in the regulated activity. See, for example, Steven Shavell, Strict Liability Versus Negligence, $9 \mathrm{~J}$ Legal Stud 1, 2-3 (1980). As applied to the regulation of employment reference practices, this analysis distinguishes the efforts employers make to improve the quality of employment references (i.e., precautions against providing falsely negative or falsely positive references) from their decision about how often to provide references at all. An employer who decides to confirm only former employees' job titles and dates of service improves the quality of information provided (inaccuracies in reporting these facts are extremely unlikely) but at the expense of reducing the quantity of information that will be available to prospective employers.

${ }^{22}$ See Restatement (Second) of Torts $§ 596$.

${ }^{23}$ Courts routinely have held that the common interest privilege extends to employment references. See, for example, Zinda, $440 \mathrm{NW} 2 \mathrm{~d}$ at 552 ("[T] has an interest in receiving information concerning the character and qualifications of the former employee, and the ex-employer has an interest in giving such information in good faith to insure that he may receive an honest evaluation when he hires new employers."); Hett, 121 NW2d at 273 (quoting Lord Blackburn) ("Where a person is so situated that it becomes right in the interest of society that he should tell to a third person facts, then, if he bona fide and without malice does tell them, it is a privileged communication."). Also note that some courts and commentators refer to a "qualified privilege" rather than a "conditional privilege." The two terms are synonymous.

${ }^{24}$ In discussing defamation claims, courts sometimes distinguish common law malice and actual malice as a basis for finding abuse of the conditional privilege. See, for example, Jolly $v$ Valley Publishing Co, 63 Wash 2d 537, 388 P2d 139, 140 (1964); Gattis $v$ Kilgo, 140 NC 106, 52 SE 249, 250 (1905); Cherry $v$ Des Moines Leader, 114 Iowa 298, 86 NW 323, 323 (1901); Kirkpatrick v Eagle Lodge, 26 Kan 384, 392 (1881). However, many com- 
subjective assessments of performance and disputed factual questions about an employee's work history, it can be difficult for employers to defeat defamation cases on a motion for summary judgment. ${ }^{25}$ Although the conditional privilege thus provides a somewhat porous shield against liability, it does appear to aid employers defending defamation actions. ${ }^{26}$ As a result, the privilege undoubtedly ameliorates the danger that the threat of defamation liability will deter employers from providing any references at all.

Despite the conditional privilege, the literature concerning employment references overflows with complaints that an insuffi-

mentators have criticized the use of the word "malice" to describe the standard for abuse of the conditional privilege. See, for example, W. Page Keeton, et al, Prosser and Keeton on the Law of Torts $\$ 115$ at 833 (West 5th ed 1984) ('The word 'malice' . . has plagued the law of defamation from the beginning.").

An employer also abuses the privilege when the defamatory matter is published for some purpose other than that for which the particular privilege is given, when the publication is made to some person not reasonably believed to be necessary for the accomplishment of the purpose of the particular privilege, when the publication includes defamatory matter not reasonably believed to be necessary to accomplish the purpose for which the occasion is privileged, or when the publication includes unprivileged matter as well as privileged matter. See Restatement (Second) of Torts §§ 603-05(a); Zinda, 440 NW2d at 551 (involving claim that employer abused privilege by publishing reason for employee's discharge in company newsletter which "reached the local hospital, where ... two of [the plaintiffs wife's] co-workers read the reference to [the plaintiffs] termination").

${ }^{25}$ Courts frequently observe that the question of whether an employer abused the conditional privilege is a factual question for the jury, precluding summary judgment if the plaintiff can offer evidence that an employer's statements might have been false. An employer thus could be forced to go to trial to defend a case that rests on no more evidence than the plaintiffs own deposition testimony contradicting the employer's judgments about his performance. See, for example, Elbeshbeshy $v$ Franklin Institute, 618 F Supp 170, 171-72 (E D Pa 1985) (denying an employer's motion for summary judgment on ground that plaintiffs testimony constituted "some evidence" that he had been terminated "for reasons of professional jealousy" rather than for "lack of cooperation" as the employer had recorded in plaintiffs employment record). Although Paetzold and Willborn find that employers often prevail on motions for summary judgment, see $30 \mathrm{Am}$ Bus $\mathrm{L} J$ at 139 (cited in note 19), their analysis ignores the selection effect that can bias inferences about legal rules based on studying litigated cases. See generally George L. Priest and Benjamin Klein, The Selection of Disputes for Litigation, $13 \mathrm{~J}$ Legal Stud 1 (1984) (concluding that the proportion of plaintiff victories in a survey of litigated cases will depend on many factors other than the stringency of the applicable legal rule). Thus, the rate of employer successes will tend to be high if they frequently choose to settle uncertain claims and litigate only those in which they are confident of prevailing.

${ }^{26}$ See, for example, Duffy $v$ Leading Edge Products, Inc, 44 F3d 308, 316 (5th Cir 1995) (holding that qualified privilege protected employer against claim that it had made false allegations of sexual harassment against the plaintiff); Garvey $v$ Dickinson College, 763 F Supp 796, 797-98 (M D Pa 1991) (holding that conditional privilege protected college dean's statement that professor was a "hostile junior colleague" in a letter of recommendation); Judd v McCormack, 27 Mass App 167, 535 NE2d 1284, 1289-90 (1989) (holding that letter and evaluation prepared after a firefighter was discharged because of alleged poor performance did not abuse the conditional privilege). 
cient amount of information is available about job applicants. ${ }^{27}$ Several commentators have urged that lawmakers should increase the quantity of available reference information by imposing on employers some form of disclosure obligation. ${ }^{28}$ Indeed, around the turn of the century, a number of state legislatures adopted so-called "service letter" statutes that require employers to furnish to former employees a letter describing their service record and stating the reason, if any, that the employee quit or was discharged. ${ }^{29}$ In 1905 , Missouri adopted its service letter statute principally to protect workers against being unable to obtain employment because their former employers had refused to provide a letter of reference. ${ }^{30}$ Legislatures in Georgia, Kansas, Oklahoma, and Texas enacted similar legislation at about the same time and for the same purpose..$^{31}$ Often enacted along with antiblacklisting laws and long before employers began to worry about the threat of defamation liability, legislators originally conceived service letter statutes as an employee rights measure. Nevertheless, such a mandatory disclosure provision also could play an important role in enhancing labor market information

${ }^{n}$ See note 2.

${ }^{28}$ See Saxton, 13 Yale L \& Policy Rev at 91-99 (cited in note 1); Swerdlow, Note, $64 \mathrm{~S}$ Cal L Rev at 1667-71 (cited in note 3).

2 For example, the Missouri statute provided:

Whenever any employe of any corporation doing business in this state shall be discharged or voluntarily quit the service of such corporation, it shall be the duty of the superintendent or manager of said corporation, upon the request of such employe ... to issue to such employe a letter, duly signed by such superintendent or manager, setting forth the nature and character of service rendered by such employe to such corporation and the duration thereof, and truly stating for what cause, if any, such employe has quit such service.

Mo Rev Stat $\S 3020$ (Stephens 1909).

${ }^{30}$ As the Missouri Supreme Court later explained in passing on the constitutionality of the statute:

Prior to the enactment of this statute a custom had grown up in this state, among railroad and other corporations, not to employ any applicant for a position until he gave the name of his last employer, and upon receiving the name, it would write to said former employer, making inquiry as to the cause of the applicant's discharge, if discharged, or his cause for leaving the service of such former company. If the information furnished was not satisfactory, the applicant was refused employment. This custom became so widespread and effected [sic] such vast numbers of laboring people it became a public evil, and worked great injustice and oppression upon large numbers of persons who earned their bread by the sweat of their faces.

Cheek v Prudential Insurance Co, 192 SW 387, 389 (Mo 1916), affd, 259 US 530 (1922).

31 1890-91 Ga Laws Part 1, Title 10, No 779; 1897 Kan Sess Laws 144; 1910 Okla Sess Laws § 3769; 1909 Tex Gen Laws 89. Early decisions in Georgia, Kansas, and Texas declared those states' service letter statutes void under free speech provisions of their respective state constitutions. See St. Louis SW Railway Co v Griffin, 106 Tex 477, 171 SW 703, 707 (1914); Atchison, Topeka \& Santa Fe Railway Co v Brown, 80 Kan 312, 102 P 459, 461 (1909); Wallace v Georgia, C \& N Railway Co, 94 Ga 732, 22 SE 579, 579 (1894). 
about job applicants. ${ }^{32}$ Only three states, however, have generally applicable service letter requirements enforceable by a private right of action against an employer who fails to provide a letter..$^{33}$ Thus, in the overwhelming majority of jurisdictions, the condi-

${ }^{32}$ Without better empirical data on how these statutes function, however, it is impossible to say definitively whether they help to overcome informational asymmetries in the labor market.

${ }^{33}$ Commentators assert that as many as fifteen states, including various combinations of California, Indiana, Kansas, Maine, Minnesota, Missouri, Montana, Nebraska, Nevada, North Carolina, Ohio, Oklahoma, Pennsylvania, Texas, and Washington have service letter statutes. See, for example, Henry H. Perritt, Jr., 2 Employee Dismissal Law and Practice, app A (3d ed 1992) (listing ten states); Saxton, 13 Yale L \& Policy Rev at 57 (cited in note 1) (citing thirteen states); Skopic, Comment, $21 \mathrm{U}$ Richmond L Rev at 439 (cited in note 2) (identifying twelve states).

My research suggests, however, that only Missouri, Montana, and Minnesota have statutes that are likely to have significant effects. In both Missouri and Montana, employers are required to provide a service letter describing the former employee's service and, according to the language of the Missouri statute, "truly stating for what cause, if any, such employee was discharged or voluntarily quit such service." Mo Stat Ann $\$ 290.140$ (West 1993); Rimmer v Colt Industries Operating Corp, 656 F2d 323, 325 (8th Cir 1981) (applying the statute). See also Mont Code Ann § 39-2-801 (1995). Aggrieved employees may bring a civil action for damages. Similarly, Minnesota's service letter requirement applies generally and has generated a significant amount of litigation during the 1990s. See Minn Stat Ann $\$ 181.933$ (West 1993); Deli v University of Minnesota, 511 NW2d 46, 50 (Minn Ct App 1994).

In Indiana and Maine, a conventional service letter is required, but there is no private right of action. Ind Code Ann \& 22-6-3-1 (West 1991 \& Supp 1997); 26 Me Rev Stat Ann $\S 630$ (West 1988). See also Hull v Central Transport, Inc, 628 F Supp 784, 792 (N D Ind 1986); Larrabee v Penobscot Frozen Foods, Inc, 486 A2d 97, 101 (Me 1984). Similarly, the Kansas statute provides no private right of action and requires only a statement of "the tenure of employment, occupational classification, and wage rate paid to the employee." Kan Stat Ann $\S 44-808$ (3) (1986). The Nevada statute does not create a private right of action. Nev Rev Stat $\S 613.210(4)$ (1995). The Texas statute requires a service letter, but a 1915 Texas Supreme Court decision declared that the provision infringed the state constitutional right to be silent that followed from the "liberty to speak." See Tex Rev Stat Ann $\S \S 5196,5196 f, 5206$ (Vernon 1987); Griffin, 171 SW at 705. Although a recent Texas Attorney General's opinion opines that the Texas Supreme Court would be likely to overrule Griffin, the provision remains void until either the legislature or the court acts to revive it. See Tex Op Atty Gen No JM-1116, 10-11 (1989).

Statutes in California, Nebraska, and Oklahoma are limited in application to public service corporations such as public utilities and railroads and their contractors. Cal Labor Code § 1055 (1989); Neb Rev Stat § 48-209 (1993); 40 Okla Stat Ann $\S 171$ (West 1986). Ohio's statute applies only to railroad companies. See Ohio Rev Code Ann $\S 4973.03$ (Baldwin 1995). No reported cases appear to have arisen under the California, Nebraska, Oklahoma, or Ohio statutes since the early twentieth century cases upholding their constitutionality. Finally, although the statutes in Nevada and Washington apply generally to all employers, they also appear to have produced no reported cases. See Nev Rev Stat $\S 613.210$ (4) (1995); Wash Admin Code $\S 296-126-050$ (1994). Perritt further cites statutes from North Carolina and Pennsylvania. These statutes, however, concern pre-termination notice and, as such, are not service-letter statutes. See NC Gen Stat § 126-35 (1989); $43 \mathrm{~Pa}$ Stat $\S 291$ (Purdon 1964). In summary, only three of these fifteen states have what appear to be strong service letter statutes. 
tional privilege is the only significant regulatory response to the activity-level problem. ${ }^{34}$

\section{Falsely Positive References}

Although disclosure obligations are quite rare, by far the least developed branch of the law regulating employment references is the effort to combat falsely positive references. An employer who either fails to disclose or affirmatively misrepresents adverse information about a former employee could conceivably be held liable for negligent or fraudulent referral. Indeed, commentators have urged courts to develop such a "wrongful referral" tort. $^{35}$ They argue by analogy to widely accepted common law rules imposing liability for misrepresentations ${ }^{36}$ and requiring disclosure in certain circumstances. ${ }^{37}$

Despite quite plausible arguments for extending existing doctrine to cover such cases, very few courts appear to have considered this theory of liability. A New York appellate court has expressly rejected wrongful referral liability in a case involving allegations of sexual misconduct against a teacher..$^{38}$ Similarly, a

${ }^{3}$ Although a comparative analysis of legal rules in other countries is beyond the scope of this Article, it is interesting to observe that German labor law appears to impose a firm obligation on employers to provide a detailed service letter for terminated employees. See Matthew W. Finkin, Employee References: A Very Small Study in Comparative Law (forthcoming in a German Festschrift, draft on file with U Chi L Rev).

${ }^{33}$ See Saxton, 13 Yale L \& Policy Rev at 91 (cited in note 1); Swerdlow, Note, 64 S Cal $L$ Rev at 1670 (cited in note 3).

${ }^{36}$ A tort action is generally available for intentional or negligent misrepresentations that result in physical harm. See Restatement (Second) of Torts $\$ \S 310,311$. Similarly, the common law of contracts provides a remedy of rescission when one party makes a misrepresentation that induces another party to assent to a contract. See Restatement (Second) of Contracts $\S 164$ (1981) ("If a party's manifestation of assent is induced by either a fraudulent or a material misrepresentation by the other party upon which the recipient is justified in relying, the contract is voidable by the recipient.").

${ }^{37}$ See Tarasoff $v$ Regents of the University of California, $17 \mathrm{Cal} 3 \mathrm{~d} 425,551$ P2d 334, 348 (1976) (holding that psychotherapist whose patient presents serious danger of violence to another has a duty to use reasonable care to protect intended victim by steps that may include warning of the threat); Restatement (Second) of Torts $\$ 551$ (listing conditions under which there is a duty to disclose); Restatement (Second) of Contracts $\$ 161$ (asserting that nondisclosure of a known fact can be a misrepresentation in some circumstances).

${ }^{38}$ In Cohen $v$ Wales, 133 A2d 94, 518 NYS2d 633, 634 (NY App Div 1987), the court flatly rejects the argument that the former employer of a school teacher who had a record of sexual misconduct was negligent for failing to disclose that fact when it recommended the teacher to another school district. The court's one-page opinion observes that:

The common law imposes no duty to control the conduct of another or to warn those endangered by such conduct, in the absence of a special relationship between either the person who threatens harmful conduct or the foreseeable victim. The mere recommendation of a person for potential employment is not a proper basis for asserting a claim of negligence where another party is responsible for the actual hiring.

See id at 634 (citations omitted). 
Michigan appeals court held that a former employer had no duty to disclose an employee's dangerous proclivities, including twenty-four disciplinary warnings for acts ranging from alcohol and drug use to outright violence. ${ }^{39}$ In another case, a former employer failed to disclose to prospective employers that its employee had been observed carrying a gun in the workplace. After obtaining and then losing a new job, the employee shot and killed several people at his subsequent employer. A Florida trial court ruled that plaintiffs could proceed with a suit alleging fraud, misrepresentation, and conspiracy arising out of a wrongful referral; the case, however, settled before trial and thus produced neither a final judgment nor an appellate ruling on this issue. ${ }^{40}$

By far the most significant judicial support for the wrongful referral theory is a recent decision of the California Supreme Court. In Randi W. $v$ Muroc Joint Unified School District, ${ }^{41}$ the court confronted a situation very similar to our hypothetical lecherous science teacher. ${ }^{42}$ Officials from no fewer than three prior employers wrote letters of reference containing extravagant praise for Robert Gadams, who was seeking a job as viceprincipal at Livingston Middle School. All of these letters, however, failed to mention a long history of sexual misconduct charges, including complaints that had caused Gadams's forced resignation from at least one of his prior employers. The court held that plaintiffs could state claims for negligent and intentional misrepresentation, but carefully limited the cause of action to situations in which "the recommendation letter amounts to an affirmative misrepresentation presenting a foreseeable and substantial risk of physical harm to a third person. ${ }^{\text {n33 }}$ It is still too early to tell whether this decision presages a nationwide trend toward greater acceptance for such claims. California employ-

${ }^{39}$ Moore v St Joseph Nursing Home, Inc, 184 Mich App 766, 459 NW2d 100, 103 (1990).

${ }^{40}$ See Jerner v Allstate Insurance Co, No 93-09472 (Fla Cir Ct, Aug 10, 1995) (ruling on motion to amend complaint and to conduct discovery on punitive damages claim). The Jerner case attracted some commentary. See Mark Hansen, Expensive Conversation Gets Expert Disqualified, 82 ABA J 25 (Mar 1996) (reporting that the case settled before trial).

" 14 Cal 4th 1066, 929 P2d 582 (Cal 1997); Former Employer May Be Sued Over Reference Letter, 10 Indiv Empl Rts 1 (BNA Aug 29, 1995) (describing the case and reporting on interviews with attorneys involved in the litigation).

${ }^{2}$ The court below in Randi W. also found support for wrongful referral liability in Gutzan v Altair Airlines, Inc, 766 F2d 135, 141 (3d Cir 1985) (imposing liability on an employment agency for misrepresenting the circumstances surrounding a job candidate's prior rape conviction in a military court). Randi W. $v$ Livingston Union School District, 49 Cal Rptr 2d 471, 482 (Cal Ct App 1995). The California Supreme Court, however, relegates Gutzan to a "cf." citation at the tail end of a string cite. 929 P2d at 592.

${ }^{43}$ Randi W., 929 P2d at 584 (Cal 1997). 
ment law undoubtedly has a distinctly pro-plaintiff character, but many other jurisdictions have followed the state's Tarasoff decision imposing a somewhat similar duty on psychiatrists. ${ }^{44}$ At present, however, wrongful referral liability remains the least developed aspect of the legal regulation of employment reference practices.

\section{Market Mechanisms for Information Sharing}

As we have seen, the direct legal regulation of employment reference practices affects both the quantity and quality of information that employers receive. Despite the obvious importance of references, however, at least two other significant market mechanisms also produce information about job applicants. First, many employers investigate prospective employees' backgrounds and seek to verify statements on their application forms. Although such an investigation might otherwise expose employers to liability for invasion of privacy, the simple expedient of requiring job applicants to sign a form granting consent to investigate immunizes investigative efforts conducted by a prospective employer. Courts find quite routinely that such a consent form protects the investigating employer from suit for invasion of privacy. ${ }^{45}$

Many firms also require job applicants to sign a prospective waiver of defamation liability, presumably to encourage their former employers to provide candid references. However, the legal effect of such waivers is considerably less clear than the effect of a consent to investigate. In some jurisdictions, those providing references may rely on a prospective waiver to confer an absolute privilege. ${ }^{46}$ In other states, a prospective waiver is unenforceable

4 See, for example, State $v$ Bright, 683 A2d 1055, 1064 (Del Super Ct 1996); Hamman $v$ County of Maricopa, 161 Ariz 58, 775 P2d 1122, 1128 (1989); Peterson v State, 100 Wash 2d 421, 671 P2d 230, 237 (1983).

45 Farrington v Sysco Food Service, Inc, 865 SW2d 247, 253 (Tex App 1993) (refusing to find invasion of privacy by employer for drug and polygraph tests when consent was given). Lack of consent is an element of the tort of invasion of privacy. There can be no action for an invasion of privacy if the plaintiff has consented, the consent has not been revoked, and the defendant has acted within the scope of the consent. See Keeton, et al, Torts $\$ 117$ at 867 (cited in note 24).

${ }^{46}$ See Baker v Bhajan, 117 NM 278, 871 P2d 374, 377 (1994) (enforcing prospective waiver of defamation liability); Hardwick $v$ Houston Lighting \& Power Co, 881 SW2d 195, 198 (Tex Ct App 1994) (holding that "[t]he release establishes [ ] consent to publication"); Thailer v LaRocca, 174 AD2d 731, 571 NYS2d 569, 571 (NY App Div 1991) (holding that "a valid release which is clear and unambiguous on its face and which is knowingly and voluntarily entered into will be enforced"). See also Cox $v$ Nasche, 70 F3d 1030, 1032 (9th Cir 1995) (holding that consent to publication confers an absolute privilege on employers against defamation, even if the employer's statements were made maliciously); Smith $v$ 
as contrary to public policy. ${ }^{47}$ But in the overwhelming majority of U.S. jurisdictions, the legal effect of a prospective waiver is uncertain; there is simply no reported case law addressing this important question. Thus, employers' attempts to stimulate the market for reference information by contractual means face a decidedly uncertain legal reception.

While most employers conduct their own investigation, a substantial number now rely on informational intermediaries to assist them in evaluating prospective employees. ${ }^{48}$ This second approach to information gathering encompasses a broad array of market sources of information: third party reference checking and pre-employment investigation services, management recruiters and headhunters, even employment agencies supplying temporary and contract labor. Each of these entities sometimes provides information about prospective employees. Defamation law and the conditional privilege establish the basic legal framework governing such informational intermediaries. Like employers themselves, headhunters and temporary employment agencies are liable for publishing false and defamatory statements about employees, and they are likewise protected by the conditional privilege. ${ }^{49}$ Unlike former employers, however, these intermediaries need not say anything defamatory in order to prevent undesirable employees from finding work. They can simply refuse to refer or recommend such individuals to their clients. Although defamation law might make clients reluctant to report the details of their dissatisfaction with a particular worker, the tort of defamation does not apply to an intermediary's refusal to refer or recommend someone for work. As a result, employers who hire

Holley, 827 SW2d 433, 436 (Tex Ct App 1992) (holding that consent alone bars any claim of defamation); Patane $v$ The Broadmoor Hotel, Inc, 708 P2d 473, 476 (Colo Ct App 1985) (holding that "plaintiffs written consent to make inquiry of her work history" confers an absolute privilege on former employer to discuss work history, "even if defamatory statements are madem); Gengler v Phelps, 92 NM 465, 589 P2d 1056, 1058 (NM Ct App 1978)

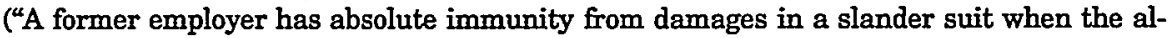
leged defamation stems from an inquiry addressed to the former employer ... made with the consent of the employee.").

${ }^{47}$ See Reece $v$ Finch, 562 S2d 195, 200 (Ala 1990) (ruling that releases as to future intentional tortious conduct, including defamation, are void as against public policy); Kellums v Freight Sales Centers, Inc, 467 S2d 816, 818 (Fla Dist Ct App 1985) (holding that contractual release from liability for intentional torts such as defamation violate public policy).

${ }^{48}$ For example, a recent survey found that 10 percent of companies engage an outside agency to perform reference checks and 21 percent use a combination of staff and an outside agency. SHRM Survey (cited in note 2).

49 See Restatement (Second) of Torts $\$ \S 558-612$ (drawing no distinction between defamation committed by employers and defamation committed by informational intermediaries). 
workers from these intermediaries can rely on them to be somewhat more "candid" in their referrals than former employers are likely to be in their employment references.

Although defamation law ordinarily governs the activities of informational intermediaries, the preparation of "investigative reports" for employment purposes also falls under the jurisdiction of the Fair Credit Reporting Act ("FCRA"). ${ }^{50}$ The statute requires the informational intermediary to notify workers when they provide an investigative report and requires employers to notify workers whenever they take an adverse personnel action on the basis of information in a report. ${ }^{51}$ In addition, those who prepare such reports must disclose, upon request from the subject, any information-except medical information-contained in their files concerning the subject of a report. ${ }^{52}$ The statute also establishes a procedure for contesting information contained in a report. ${ }^{63} \mathrm{Fi}$ nally, the FCRA codifies a strong conditional privilege for all those who prepare, contribute information to, or receive covered investigative reports. Only false information furnished with "malice or willful intent to injure" is actionable. ${ }^{54}$

\section{E. Calls for Reform}

Most commentators appear to be dissatisfied with the legal status quo. Many authors writing on the subject have proclaimed that defamation law makes it impossible to obtain sufficient information about job applicants. ${ }^{55}$ Indeed, the Society for Human Resource Management ("SHRM") recently released the results of a survey showing that a significant percentage of its members believe they are getting inadequate reference information..$^{56}$ Legal commentators have responded to these complaints with various proposals for reform. Some would make it more difficult for plaintiffs to prevail in defamation suits. ${ }^{57}$ Others would impose on for-

${ }^{50}$ See Pub L No 90-321, Title VI, $\S 602$, as amended by Pub L No 91-508, Title VI, $\S 601,84$ Stat 1128 (1970), codified at 15 USC $\S \S 1681$ et seq (1994).

${ }^{31}$ See 15 USC $\$ \$ 1681 \mathrm{k}, 1681 \mathrm{~m}$.

${ }_{52}^{52}$ See 15 USC $\$ 1681 \mathrm{~g}$.

${ }^{s 3}$ See 15 USC \$ 1681i.

${ }^{54}$ See 15 USC $\$ 1681 \mathrm{~h}$.

ss See note 2.

${ }^{56}$ See SHRM Survey (cited in note 2). Participants in the survey were asked, for a variety of factors, whether they were receiving an inadequate level of information on potential employees. The percentage of respondents who viewed information on the various factors as inadequate varied from 1 percent for dates of employment to 52 percent for personality traits and 54 percent for violent/bizarre behavior. Id.

${ }^{57}$ See Lewis, Ottley, and Mersol, 54 Mo L Rev at 855-62 (cited in note 3); Saxton, 13 Yale L \& Policy Rev at 79 (cited in note 1). 
mer employers some form of disclosure obligation. ${ }^{58}$ Finally, a student author would, within certain limits, permit private contracts to vary the assignment of liability under defamation law. ${ }^{59}$

Although courts and legislatures have shown a great deal of interest in the problem of regulating employment reference practices, their response to these calls for reform has been quite modest. A number of state legislatures have recently adopted statutory provisions conferring a "good faith" immunity on those who provide employment references. ${ }^{60}$ These enactments vary somewhat in their specifics, but none seriously modifies the existing structure of liability under the common law. Employers remain subject to defamation suit for falsely negative references, and the legislation typically codifies the existence of a conditional privilege for providing reference information. ${ }^{61}$ It remains to be seen whether such provisions will significantly increase the burden on plaintiffs attempting to prove abuse of the privilege. However, a plain reading of the language most commonly used in these statutes suggests that dramatic change is unlikely. ${ }^{62}$

\footnotetext{
${ }^{58}$ See Saxton, 13 Yale L \& Policy Rev at 91-99 (cited in note 1); Swerdlow, Note, $64 \mathrm{~S}$ Cal $L$ Rev at 1661 (cited in note 3).

${ }^{59}$ See Horkan, Note, 79 Va L Rev at 546-47 (cited in note 3) (concluding that employers and employees should be free to contract around defamation law if certain conditions are met).

${ }^{\infty}$ These states include: Alaska, Arizona, California, Colorado, Florida, Georgia, Idaho, Louisiana, Maine, Minnesota, New Mexico, Ohio, Oklahoma, Oregon, Pennsylvania, South Carolina, South Dakota, Wisconsin, and Wyoming. See Alaska Stat § 09.65.160 (1996); Ariz Rev Stat Ann $\S 23-1361(B),(C)$ (West 1995); Cal Civ Code $\$ 47$ (West 1992 \& Supp 1997); 1994 Colo Rev Stat § 8-2-114(2); Fla Stat Ann I § 768.095 (West 1997); Ga Code Ann I § 34-1-4 (Michie Supp 1997); Idaho Code § 44-201 (Michie 1997); La Rev Stat Ann § 23:291 (West Supp 1997); 26 Me Rev Stat Ann § 598 (West Supp 1996); Minn Stat $\S 181.933$ (1996); NM Stat Ann § 50-12-1 (Michie Supp 1997); Ohio Rev Code Ann § 4113.71 (Anderson 1997); 40 Ok Stat Ann § 61 (West Supp 1997); Or Rev Stat 30.178 (1995); $42 \mathrm{~Pa}$ Cons Stat Ann § 8342 (Purdon 1982); SC Code Ann § 41-1-65 (West Supp 1996); SD Cod Laws \& 60-4-12 (Supp 1997); Wis Stat Ann § 895.487 (West 1997); Wyo Stat Ann 27-1-113 (Michie Supp 1996).

${ }^{61}$ For example, the Alaska statute provides that "[a]n employer who discloses information about the job performance of an employee or former employee to a prospective employer ... is presumed to be acting in good faith and, unless lack of good faith is shown by a preponderance of the evidence, may not be held liable for the disclosure or its consequences." Alaska Stat $\S 09.65 .160$ (Michie 1996). The presumption of good faith is rebutted upon a showing that the employer "(1) recklessly, knowingly, or with a malicious purpose disclosed false or deliberately misleading information;" or (2) disclosed information in violation of a protected civil right of the employee or former employee. Id. This standard simply codifies a conventional conditional privilege.

${ }_{62}$ See the example discussed in note 61.
} 


\section{EMPLOYEE TURNOVER, INFORMATION, AND EFFICIENCY}

The many complaints about inadequate information suggest that employment reference practices are a significant problem. But this apparently serious market failure has generated a relatively modest regulatory response. The puzzle is why lawmakers have not responded more aggressively. Commentators' proposed reforms are plausible policy options, but, as the remainder of this Article demonstrates, their advocates have not fully appreciated the complexity of the problem. Indeed, this complexity may well explain the apparent reluctance of lawmakers to alter dramatically the contours of existing law. My analysis focuses on the difficulty of regulating information flows and on the complex interactions among the various economic and legal forces that affect employment reference practices. In this Section, I develop a theoretical framework with which to analyze the relationship between these labor market phenomena and the law governing employment reference practices. This framework helps us to understand better both the nature of the problem and the effects of possible remedial measures.

I begin with the observation that labor market efficiency depends to a great extent on matching workers to jobs for which they are well suited. Employee turnover-the process by which people move from one job to another-is an essential mechanism for improving job matching. ${ }^{63}$ But under conditions of imperfect and asymmetric information, turnover also can cause inefficient mismatching, churning, and scarring. It is natural to ask whether regulation could correct these labor market failures. I show that first-best efficiency is unattainable. Inherent limitations on the regulation of information disclosure prevent legal rules from achieving the required full-information equilibrium, and the complexity of the job assignment problem makes direct behavioral regulation similarly impossible. Finally, I show that efforts to develop market mechanisms for providing reference information confront difficult coordination problems. Even if these barriers to collective action could be surmounted, private efforts would confront the same obstacles to achieving a fully efficient, fullinformation equilibrium that prevent regulatory solutions from achieving that objective. 


\section{A. Incomplete and Asymmetric Information About Productivity}

Although employers would like to know anything about a job applicant that might affect his or her productivity, the very nature of much of that information limits their ability to acquire it. Of course, some characteristics are comparatively easy to verify. Employers seldom have any trouble determining whether someone possesses a valid driver's license. Similarly, it is a routine matter to verify educational credentials, professional certifications, and security clearances. With proper consent from job applicants, for example, secondary schools and universities readily disclose degree information and transcripts. However, certain types of information present special problems for employers.

A job applicant's prior work history-including job titles, compensation, responsibilities, and accomplishments-plays a significant role in pre-employment screening. But applicants frequently misrepresent themselves, most commonly exaggerating their responsibilities and accomplishments. ${ }^{64}$ When prospective employers attempt to verify these facts, applicants' former employers often will confirm only job titles and dates of service. ${ }^{65}$ The prospective employer thus may find it necessary to discount applicants' self-serving accounts of their prior achievements because of an inability to verify that information.

Employers' informational problems also have a temporal element. Some characteristics of employees, which I will call "experience traits," become apparent only after an extended period of observation. Experience traits are seldom discovered during a conventional interview process; employees who are, for example, predisposed to violence, to substance abuse, or to engaging in sexual misconduct may function quite normally for substantial periods of time. Instead, employers ordinarily learn about such traits after an employee engages in inappropriate behavior on the job: a manager's female subordinates complain frequently about sexual harassment; a forklift operator causes several accidents; a security guard uses excessive force to evict a trespasser. ${ }^{66}$ While

${ }^{64}$ See Gatewood and Feild, Human Resource Selection at 402-03 (cited in note 1). Experts appear to agree that, depending on the position and industry, between 10 and 30 percent of all job applicants distort the truth or lie on their resumes. See Samuel Greengard, Avoid Negligent Hiring: Are You Well Armed to Screen Applicants?, 74 Personnel J 84, 84 (Dec 1995).

${ }^{65}$ See Bureau of National Affairs, Reference Requests on Former Employees: Selection Procedures \& Personnel Records 16 (Personnel Policies Forum No 114, Sept 1976) ("BNA Survey").

${ }^{66}$ See, for example, Martin v Cavalier Hotel Corp, 48 F3d 1343, 1349 (4th Cir 1995) (forcible sexual assault by hotel manager); Lusby v T.G. \& Y. Stores, Inc, 749 F2d 1423, 1428 (10th Cir 1984), vacated, 474 US 805 (1985) (Security guard used chokehold and 
an employees' future behavior may be impossible to predict, his or her prior misconduct often is objectively verifiable and could be reported by a former employer. However, problems arise when prospective employers attempt to learn about applicants' prior sexual harassment complaints, violent behavior, workplace accidents, disciplinary actions, or attendance records. ${ }^{67}$ Providing such negative information creates a risk of defamation liability while offering few clear benefits to the referring employer. Indeed, the available empirical evidence suggests that former employers are less likely to reveal employee misconduct than any other information about the employee. ${ }^{68}$ Because prospective employers rarely have unfettered access to the details of prior misconduct, highly relevant information often remains concealed from those who must make hiring and job assignment decisions. As a result, an employer may mistakenly hire someone who is poorly matched for the relevant position.

Finally, many other important productive characteristics require a subjective assessment of personality traits and performance over time. This type of information combines the temporal problems I have just described with an additional element. No objective means exist for measuring and verifying these traits. ${ }^{69}$ Human resource managers and line supervisors inevitably form opinions about individual workers, but these subjective assessments require an extended period of observation and are inherently unverifiable. Nevertheless, such judgments play a critical role in selecting and assigning employees. Because employer poli-

struck plaintiff with pistol during effort to detain him in shoplifting incident.).

${ }^{6}$ In one particularly memorable case, an insurance company discharged an employee after observing him bring a gun to work on several occasions. Responding to a prospective employer's inquiries, the former employer provided a neutral reference that omitted any mention of the gun-toting incidents. After the second employer fired him, the employee returned to the company cafeteria and shot and killed several members of the company's management. See Jerner v Allstate Insurance Co, No 93-09472 (Fla Cir Ct, Aug 10, 1995).

${ }^{*}$ A recent survey found that although most employers were satisfied with the information they received about applicants' dates of employment (96 percent), eligibility for rehire (65 percent), and qualification for a particular job (56 percent), a mere 11 percent of employers felt that they received adequate information about "violent/bizarre behavior." See SHRM Survey (cited in note 2).

Psychological test batteries exist that measure some of the traits about which employers may be concerned. See James N. Butcher, Use of the MMPI in Personnel Selection, in James N. Butcher, ed, New Developments in the Use of the MMPI 165, 188 (Minnesota 1979). One important limitation of these tests, however, is that they were developed in a clinical rather than an industrial setting. The studies establishing their validity and reliability for identifying psychopathology in mental patients therefore may be insufficient to support their use as personnel screening devices. See id. My discussion in the text should be read to apply to characteristics for which valid testing devices are not available at a reasonable cost. 
cies usually prohibit sharing these performance appraisals with anyone outside the company, prospective employers often must make initial hiring and job assignment decisions without the benefit of this information. ${ }^{70}$

As if the problem of incomplete information were not enough to prevent efficient employee selection and assignment, participants in the labor market are also asymmetrically informed about many worker characteristics. Consider for a moment an analogy between the labor market and the market for used cars. A familiar feature of the used car market is the fact that sellers ordinarily know more than buyers about the condition of the cars they are offering for sale. When potential sellers may choose either to sell or to keep the car that they own after privately observing its qualities, buyers rationally fear that owners will keep the good cars and sell the lemons. This tendency to sell lower quality items is an example of a phenomenon economists call adverse selection, or more colorfully, a "market for lemons."71 The consequences of adverse selection range from depressing the price in a market for lemons to eliminating altogether the market for such goods. ${ }^{72}$

The labor market, like the used car market, can be understood as a market for lemons. The hiring and firing practices of employers in the labor market provide the mechanism for adverse selection. Employers hire new workers from a pool that includes new entrants to the job market; re-entrants; workers who have been displaced by plant closings, laid off due to slack work, or discharged for cause; and workers who quit their former jobs. ${ }^{73}$ Focusing for a moment on workers who have been discharged or laid off, we see that current employers occupy an economic position similar to that of car owners. Just as an owner learns about her car's reliability, an employer has an opportunity to observe each worker's productive characteristics. Firms predictably tend to retain their most productive employees and to discharge or lay off

${ }^{70}$ See sources cited in note 2.

"See George A. Akerlof, The Market for "Lemons": Quality Uncertainty and the Market Mechanism, 84 Q J Econ 488 (1970).

${ }^{72}$ See Michael Rothschild and Joseph Stiglitz, Equilibrium in Competitive Insurance Markets: An Essay on the Economics of Imperfect Information, 90 Q J Econ 629 (1976).

${ }^{73}$ In practice, employers may not be able to distinguish reliably among various types of workers in the pool of prospective employees. As my later discussion of employee churning will show, for example, workers who quit may have characteristics quite similar to those of employees who are discharged or laid-off. See Section II.B.2 (discussing employee "churning"). Nevertheless, these categories provide a convenient means of identifying more or less distinctive groups of job seekers. 
those who are less productive. ${ }^{74}$ As a result, employers should expect that the average worker who has been discharged or laid off will be less productive than one drawn at random from the pool of all workers. The economic theory of adverse selection thus predicts that firms will reduce their wage offers to these unemployed workers. ${ }^{75}$ The available empirical evidence appears to support this intuitively plausible description of firm behavior. ${ }^{76}$

\section{B. Information and Labor Market Efficiency}

What then are the consequences of these informational problems? How do they affect efficiency in the labor market? As I

"See Greenwald, 53 Rev Econ Stud at 325 (cited in note 8) (noting that adverse selection in the labor market can severely limit a worker's freedom to change jobs). Employees' lack of productivity may affect only a single firm or influence productivity in many jobs at many employers. Firm-specific productivity is of course an important efficiency concern. However, I focus in the text on workers' more general productive characteristics because incomplete and asymmetric information about these traits may cause inefficient employee turnover.

${ }^{75}$ See Greenwald, 53 Rev Econ Stud at 325 (cited in note 8) (noting that adverse selection lowers wages in the job market). If discharged and laid-off workers are indistinguishable from others in the pool of unemployed, then firms will reduce, by a somewhat smaller amount, their wage offers to all unemployed workers. Indeed, even currently employed workers may be searching for work under the threat of discharge and therefore be "lemons." For the sake of simplicity, one might prefer to focus on the comparatively obvious selection effects associated with layoff and discharge. But my later analysis of employee churning demonstrates that more subtle forms of adverse selection are equally important. See Section II.B.2.

${ }^{76}$ In a recent article, Robert Gibbons and Lawrence Katz discuss how asymmetric information about productivity influences wage patterns in the market for white collar workers. Gibbons and Katz, $9 \mathrm{~J}$ Labor Econ at 351 (cited in note 8). Gibbons and Katz construct a two-period model in which firms decide whether to lay off or retain employees af ter observing their productivity in the first period. In equilibrium, they show that employers choose to lay off their least productive workers, that other employers infer that laid-off workers are less productive, and that these employers therefore offer them a low wage. Because no such inference is justified concerning workers who lose their jobs as a result of a plant closing, Gibbons and Katz predict that laid-off workers will earn lower reemployment wages than workers displaced by plant closings. Their model also predicts that laid-off workers will have longer postdisplacement unemployment spells. Finally, if the market concludes that laid-off workers are "lemons" solely because they have been laid-off, then predisplacement wages should not differ by cause of displacement. Using data from the 1984 and 1986 Displaced Workers Supplements to the Current Population Survey, Gibbons and Katz find strong support for all three predictions of their model. See id at 353.

These empirical results are especially striking because Gibbons and Katz do not control for two factors that tend to diminish the chances of observing this wage pattern. First, plant closings often have a severe economic effect on areas in which the closed plant was a major source of employment. We would ordinarily expect these concentrated local employment losses to make re-employment wages lower and unemployment spells longer for those displaced by a plant closing. Second, some employers might find it difficult to confirm that an applicant lost her job in a plant closing rather than as the result of a layoff. Any uncertainty about this critical information tends to diminish the chances of observing different wages and unemployment spells for the two groups. 
have suggested already, incomplete and asymmetric information cause three significant inefficiencies: mismatching, churning, and scarring. The next three subsections describe each of these labor market failures.

\section{Mismatching.}

Just as individuals differ in their productive characteristics, so also jobs differ in the demands they place on workers. The dynamic market process of employee turnover-driven by workers' preferences and employers' hiring and firing decisions-ultimately determines where each person will work. Thus, some people become dissatisfied with their jobs and quit while others learn new skills and seek promotions. Employers hire promising new applicants and lay off or discharge unproductive incumbent employees. Labor market efficiency depends to a great extent on matching employees' strengths and weaknesses to the requirements of the work that they perform. Mismatching occurs whenever workers are not employed at the jobs in which they will be most productive. ${ }^{77}$

The problem of mismatching is as varied as workers and occupations. ${ }^{78}$ Most of us probably think first of someone who lacks the skills or diligence to perform his current job: an incompetent employee who botches every assignment or a lazy slug who completes tasks only when forced to do so. Nevertheless, the obverse problem may be equally common. Some employees are simply too good for their present positions, as when a highly talented worker languishes in an unchallenging job at a poorly managed company. Mismatching also occurs when a person with valuable skills in

"Although output-maximizing matching is a generally desirable objective, it may often conflict with individual utility maximization. Indeed, some theoretical models of the general assignment problem suggest that the most preferred match for employers will be the least desirable match for employees and vice versa. See Alvin E. Roth, Stability and Polarization of Interests in Job Matching, 52 Econometrica 47, 56 (1984) (examining matches in the core of a noncooperative bargaining game between employers and employees). I thus use the term "inefficient" somewhat loosely when I speak of mismatching. I intend to appeal to what I take to be a widely shared intuition that we are ordinarily better off with a larger rather than a smaller total surplus to divide among members of society. Moreover, for the types of severe mismatching with which we should be most concerned (for example, substance abusers operating vehicles and machinery, and sexual predators holding jobs that give them authority over or access to potential victims), I doubt that anyone would argue that distributional concerns should take precedence over efficient matching.

${ }^{78}$ For the moment, I leave to the side situations involving firm-specific mismatches. The possibility that employers have firm-specific reasons for preferring one worker over another undermines the potential effectiveness of regulatory measures that rely on restricting employers' freedom to hire and fire at will. See Section II.C.2. 
one area tries to perform work that requires very different abilities. Thus, a superb engineer may be incapable of managing a large research and development lab, and a great scholar may make a very poor salesman.

There is, however, one type of mismatching that is especially significant in the analysis that follows. A mismatch may result from a specific interaction between a worker's propensities and the nature of the job he is performing. Thus, someone with a propensity to respond violently to stress should not work in a stressful environment. Someone with a tendency to behave recklessly should not work in a safety-sensitive position. Someone with a history of embezzlement or financial misconduct should not work in a position of financial responsibility. Someone prone to engaging in sexual misconduct should not work in situations that create opportunities to exploit victims. In each case, the risk of loss from misconduct or malfeasance reduces substantially the employee's net productivity in a particular type of job.

Although employers perceive clearly the benefits of matching, they often have difficulty learning relevant information. As we have seen, it is inherently difficult to verify subjective assessments of employee productivity. Experience traits become apparent only over time, and employers concerned about the threat of defamation liability often share no more than the most rudimentary facts about their former employees. Armed with incomplete information about applicants, employers inevitably make mistakes in hiring and job assignment. The resulting mismatches often produce only trivial effects on productivity, but sometimes they can cause tragic social losses. Planes, trucks, and trains crash. ${ }^{79}$ Customers become victims of rape, assault, and embezzlement. ${ }^{80}$

79 For example, in California, a chartered bus swerved off a highway near Palm Desert and slid fifty feet down an embankment, injuring twenty-six girls and four chaperones headed for a weekend retreat. The driver admitted that he had taken cocaine the morning before the crash. Marla Cone, Drug Testing on the Way for Bus Drivers, Los Angeles Times B1 (Feb 6, 1992). On January 19, 1988, a Trans-Colorado plane crashed near Bayfield, Colorado, killing both pilots and seven passengers. Investigators discovered that one of the pilots had used cocaine the night before the fatal crash. In addition, his pre-employment record included a nonfatal crash landing on the wrong runway, a suspended driver's license, and five moving violations in three years. His copilot had been fired from another regional airline for poor performance, and his record included two alcohol-related driving convictions and one alcohol conviction not related to driving. At the time, the FAA did not require airlines to check for alcohol or drug-related driving convictions of pilots. Julie Schmit and John Ritter, Marginal Pilots Put Passengers' Lives at Risk, USA Today A1 (Sept 26, 1995).

${ }^{\text {so }}$ See, for example, Ohio v Mitchell, 1995 Ohio App LEXIS 5071, *9 (1995) (Defendant, employed by Adelphia Cable, was charged with rape, attempted rape, felonious assault, aggravated burglary, and kidnapping in connection with three separate incidents that oc- 
Employers naturally use whatever information is available to hire and assign employees in a way that minimizes these risks. Information plays an equally important role when employers choose to discharge current employees. By observing employees on the job, firms gain valuable insight into workers' productive characteristics. For example, an employer may discover that a forklift operator tends to be somewhat reckless, a propensity that creates the risk of serious harm. The employer thus promotes efficient matching by discharging the worker from a position for which he is particularly unsuited.

The more difficult it is for other employers to obtain information about job applicants s however, the less likely it is that such selective discharges will improve match quality. Somewhat perversely, employers may have the greatest incentive to conceal information about former employees precisely when that information would be most useful to prospective employers. By remaining silent, the discharging employer reaps the benefit of returning an unproductive or dangerous employee to the general labor pool and simultaneously avoids the risk of a defamation suit. ${ }^{81}$ But this privately rational discharge decision increases the risk that some other employer will unwittingly hire an undesirable worker. Without adequate information about the worker, chances are good that match quality will not improve. Thus, the same impulse to discharge undesirable employees that ordinarily produces efficient matching can also cause what I have called churning.

\section{Churning.}

In essence, employee churning is unproductive turnover. ${ }^{82}$ Recall for a moment the story of the teacher that I recounted in

curred after he used his employment with Adelphia as a means to enter the victims' homes.); DRR v English Enterprises, CATV, Division of Gator Transportation, Inc, 356 NW2d 580, 582 (Iowa Ct App 1984) (Victim brought action against cable television franchisee and its independent contractor who employed the installer who raped her.).

s1 Recall that employers face a serious threat of defamation liability only when they disclose negative information about former employees. If employment references are the principal means by which prospective employers learn such information about job applicants, the loss of this source of information will often affect the ability of employers to match workers to appropriate jobs.

Although employee churning incorporates the notion of asymmetric information about productivity that drives a market for lemons, the analysis of churning involves additional factors that play no role in a traditional lemons model. First, churning is a dynamic process that occurs only when employee turnover produces no improvement in match quality and no significant contribution to deterrence, incapacitation, or signaling. See notes 89-97. In contrast, a market for lemons can develop whenever buyers and sellers have asymmetric information about product quality. Second, employee churning involves three rather than two interested parties. The former employer, the prospective employer, 
the introduction. ${ }^{83}$ His employer discovered information about him that led the employer to conclude that he should not be teaching eighth-grade science classes. After he agreed to resign, however, prospective employers were unable to discover the facts surrounding his departure. Without this critical information, there was nothing to prevent him from obtaining a position identical to the one he had held prior to the allegation of sexual misconduct. As this example illustrates, employee churning occurs because of an informational asymmetry in the labor market. Former employers are notoriously reluctant to provide candid assessments of applicants' productivity ${ }^{84}$ As a result, firms often learn critical facts about employees only after hiring them.

Employee churning is inefficient in two distinct ways. ${ }^{85} \mathrm{First}$, the original employer incurs the substantial economic costs of discharging the undesirable employee and recruiting, screening, and training a replacement. Every prospective employer at which the discharged employee seeks work incurs the costs of screening. And his new employer bears the cost of training him. The net result of this job change is to improve productivity at the original employer, but also to produce an equal and opposite effect on productivity at the worker's new employer. Thus, the transaction costs of turnover are a pure social cost. ${ }^{86}$

and the job candidate all play an important role in the market dynamics of churning. A market for lemons requires only a buyer and a seller.

* See note 4 and accompanying text.

\& Some human resource theorists argue that a major cause of the lack of predictive validity of reference checks is the reluctance of employers to provide negative information about employees. See, for example, Stephen J. Carroll, Jr. and Allan N. Nash, Effectiveness of a Forced-Choice Reference Check, 35 Personnel Administration 42, 42 (Mar-Apr 1972). Others have observed that employers sometimes write overly positive recommendations of marginal employees in an effort to get rid of the person by making them look more attractive to prospective employers. See, for example, Milton L. Blum and James C. Naylor, Industrial Psychology: Its Theoretical and Social Foundations 168 (Harper Row rev ed 1968).

${ }^{85}$ Discharges and the resulting employee turnover can potentially enhance efficiency by promoting matching, deterring misconduct, incapacitating dangerous workers, or signaling employee productivity. In the remainder of this subsection, I explain how asymmetric information impedes these potentially beneficial effects of discharge and describe when those effects are most likely to be absent. The term "churning" refers only to situations in which these effects are negligible.

* Although estimates of turnover costs vary widely for different types of jobs, these costs can be quite considerable. See Patrick Dunn, Pre-Employment Referencing Aids Your Bottom Line, 74 Personnel $J 68,68$ (Feb 1995) (citing estimates that turnover costs average about 1.5 times the annual salary for the position in question); John J. Hogan, Turnover and What To Do About It, 33 Cornell Hotel \& Restaurant Admin Q 40, 40 (Feb 1992) (estimating turnover costs for managerial personnel at between $\$ 17,000$ and $\$ 20,000$ per employee). 
Far more troubling, however, is the fact that employee churning can cause severe mismatching. Prospective employers often fail to learn about undesirable characteristics that make a discharged worker unsuited for a particular type of job. Without this information, subsequent employers cannot take specific precautions in job assignment or supervision that would prevent further social losses. For instance, the second school in our earlier example could have restricted or more closely monitored the teacher's contact with individual students, or it might have hired him to work in a team with another teacher. ${ }^{87}$ As this example suggests, once someone has learned a trade or profession, it is possible that the most efficient response to his misconduct will be to modify a job to accommodate the undesirable characteristic. ${ }^{88}$

In many cases, however, such precautions will be ineffective or cost so much as to make it uneconomic for the discharged employee to continue in the same occupation. Some employee characteristics create a risk of tragic losses: a plane crash, a sexual assault, or a serious industrial accident. Unless employer precautions can virtually eliminate any unusual risk of these severe harms, the offending employee should find a lower-risk job. Thus, we have an intuitive sense that child sex offenders should not be working in day care centers and that reckless drivers should not be operating delivery trucks. The lack of available information about discharged employees that produces employee churning creates the danger that employers will be unable to act on these intuitions.

A disciplinary discharge and the resulting employee turnover becomes churning, however, only when it serves no economically useful function. Discharges for misconduct or poor performance can enhance labor market efficiency in four distinct ways: (1) by improving match quality; (2) by deterring employee misconduct; (3) by incapacitating dangerous or unproductive employees; and (4) by signaling workers' productive characteristics to prospective employers. Let us consider each of these possibilities in turn.

First, discharge can improve match quality by moving an employee to a job in which he or she is more productive. Thus, for example, a truck driver discharged for failing a drug test or for

${ }^{87}$ Similarly, the gun-toting insurance claims adjuster in Jerner, No 93-09472 (Fla Cir Ct, Aug 10, 1995), could be subject to unannounced searches for weapons, and a drugabusing truck driver might be required to submit to sobriety or psycho-motor testing before and during each work shift.

${ }^{83}$ This argument bears a striking similarity to the structure of statutory duties to accommodate disabled workers. See Conclusion (discussing application of the analytic framework to disability discrimination law). 
reporting to work under the influence of alcohol might take a new job as a day laborer. This occupational change presumably decreases somewhat the risk that the former driver will cause harm to himself or others. However, the fact that the former and prospective employers often possess asymmetric information about employee misconduct significantly reduces the likelihood that match quality will improve. ${ }^{89}$ Suppose, for example, that the driver applies for work at another trucking company and claims to have quit his prior job because of low pay or poor working conditions or for some other innocent reason. If his former employer's reference policy permits only disclosure of his job title and dates of service, it is quite likely that he will soon find himself behind the wheel of a truck again. However, this analysis obviously does not apply to employee misconduct that produces a public record. Prospective employers would have little trouble discovering a drunk driving conviction or a record of moving violations. ${ }^{90}$ An improved match is least likely and churning is thus most likely to occur when it is difficult for prospective employers to learn the reason for a discharge.

Second, the threat of discharge may deter employee misconduct, since employment termination can impose a substantial cost on discharged employees. Whether or not this deterrent incentive succeeds in a particular situation depends largely on the reason why employees are unproductive. If employees have chosen to exert themselves less fully or control their actions less carefully than they could, the threat of discharge will deter shirking to the extent that the supply of effort or self-control is responsive to the financial and psychic sanction of discharge. Another possibility, however, is that some employees are innately unproductive because of certain physical or psychological characteristics. If these characteristics are outside their control, then the sanction of discharge can have no deterrent effect. The risk of inefficient churning thus is greatest for employees in this category. $^{91}$

Moreover, improving match quality requires that there be work available in which the discharged employee can be more productive. Some worker characteristics are equally undesirable for a wide range of jobs in the economy. For example, chronic tardiness probably has roughly equivalent effects on productivity in a broad class of white collar jobs. Moving undesirable workers among these positions cannot improve match quality. Nevertheless, discharge may deter the misconduct or signal to other employers that such workers are troublesome.

${ }^{\circ}$ For example, the SHRM Survey found that 42 percent of surveyed companies checked the driving records of prospective employees. See SHRM Survey (cited in note 2).

${ }^{91}$ Psychologists are far from agreeing on what determines an individual's future propensity to commit antisocial acts. For example, an extensive literature debates whether it 
Even for those workers who might otherwise be expected to respond to the threat of discharge, asymmetric information reduces the costs that they suffer in the event of being discharged, thus reducing any potential deterrent effects. The more difficulty prospective employers have discovering the truth about the work history of discharged employees, the less trouble those employees are likely to have finding new jobs that are as attractive as their prior positions. ${ }^{92}$ Moreover, even if discharged workers experience significant losses, firms still have an economically excessive incentive to use discharge as a disciplinary device. Employers gain the full benefit of deterring misconduct by remaining employees, but they bear only part of the cost of the discharge. The private benefits of discharging an undesirable employee include both the deterrent effect of the discharge and the expected improvement in productivity that results from hiring a more suitable replacement worker. To compute the net social benefits of this discharge, however, we must deduct the loss in productivity suffered by the undesirable worker's new employer. This divergence between the private and social benefits of the discharge is a somewhat more rigorous way of expressing the intuition that an employer who passes his or her "dead wood" downstream without warning subsequent employers has done something wrong. ${ }^{93}$

is possible to predict violent behavior. See, for example, John Monahan, The Prediction of Violent Behavior: Toward a Second Generation of Theory and Policy, 141 Am J Psych 10, 11 (1984); John Monahan, The Clinical Prediction of Violent Behavior (DHHS 1981).

${ }^{92}$ It is also possible that having less information about job candidates will make employers more likely to rely on labor market signals and therefore increase the risk of scarring. See Section II.B.3. However, the danger of scarring is reduced substantially when employers cannot distinguish between discharged workers and those who have quit. Because discharged workers are a comparatively small fraction of the total pool of job seekers, the mere fact of a prior job separation conveys considerably less information than the knowledge that someone has been discharged.

${ }^{93}$ To those who do not share my intuition on this question, I can only explain how this practice can decrease social welfare. In deciding whether or not to discharge an undesirable employee, an employer simply ignores the possibility that some other employer will end up with an equally unproductive worker-job match. Similarly, the discharging employer has few incentives to provide prospective employers with the information about the worker's productive characteristics that it has learned during the period of employment. The combination of these two factors distorts the original employer's decision about discharge as surely as freedom from liability for water or air pollution distorts the production decisions of potential polluters. Discharges of undesirable workers, like industrial emissions of airborne pollutants, impose an externality on others who use the common resource. This analogy is less than perfect, however, because the employer's productive process did not alter the worker to make him or her undesirable as, for example, the combustion of fossil fuels alters the air by producing air pollutants.

A somewhat better metaphor, for which I thank my colleague Mary Anne Case, might be that of prospectors panning for gold in a stream. Just as the prospector must decide whether to toss the tailings back into the stream, so also the employer must decide whether and how to return employees to the general labor pool. I suspect that if property 
A third potential benefit of discharge is that it may produce a period of occupational incapacitation during which a dangerous or unproductive employee can do no harm. Some individuals are undoubtedly so likely to impair productivity in the workplace that society would be better off if they were to remain unemployed. Discharge thus helps to keep these individuals at least temporarily out of work. However, as we saw in discussing the deterrent effects of discharge, asymmetric information about employee productivity shortens the expected period of unemployment. Moreover, it seems likely that the number of discharged workers who could be employed profitably in some job far exceeds the number of those who are seeking work but nevertheless should remain permanently unemployed. ${ }^{94}$ Even so, the market process of discharge, reemployment, and repeated discharge may be the most efficient means of incapacitating this comparatively small group of totally unproductive individuals. ${ }^{95}$ Our concerns about employee churning thus should focus on those workers who unquestionably can produce a marginal product in excess of the legal minimum wage.

rights to a stretch of stream are well defined, prospectors will separate the tailings from the stream whenever the expected future benefit of doing so exceeds the cost. In contrast, employers have no similar claim on a portion of the labor pool. We may therefore expect them to behave more like prospectors exploiting a common resource. They will maximize their private returns without regard for the effects that their actions may have on the total returns that can be obtained from the common pool. Without well defined stakes, prospectors have every incentive to dump their tailings anywhere that they do not themselves expect to be working. Similarly, employers have an incentive to pass their dead wood "downstream" to other employers.

24 Here it is important to note that only those who are not otherwise incapacitated and who are seeking work should be considered possible targets for this beneficial incapacitation effect of discharge. Thus, we must exclude from consideration anyone who is either currently incarcerated or receiving total disability benefits.

${ }^{*}$ By considering medical testimony and workers' job prospects, administrative schemes such as Social Security Disability Insurance and worker's compensation evaluate the fitness for employment of workers who do not wish to work. However, these programs do not address those who want to work but perhaps should not. Repeated discharge may be a cost-effective way to identify such employees.

The criminal justice system is an important alternative means of incapacitating certain dangerous individuals: criminal sentences normally include a period of incarceration, and a record of certain types of criminal convictions disqualifies the released ex-convict from some employment opportunities. It is ultimately an empirical question what mix of criminal incarceration and labor market discharges optimally protects us against harm. Because the sanction of unemployment is considerably less severe, discharge may well be a better penalty for chronically negligent and dangerous, but not morally blameworthy, conduct. But we should also bear in mind that employers have a socially excessive incentive to rely on discharge as a discipline device. See text accompanying note 93 . Without better evidence concerning the social costs and benefits of these alternatives, any policy prescription rests on little more than speculation. 
The fourth and final constructive role for discharge is as a labor market signal. Employers who observe that an applicant has moved frequently among jobs may be able to infer that he is unproductive. Such signaling is efficient to the extent that it forces these unproductive individuals into jobs in which their undesirable characteristics cause fewer problems. Thus, for example, employers hiring for safety-sensitive positions might establish a policy requiring a record of stable prior employment experience. Once again, however, incomplete information undermines these potentially beneficial effects. Employers often are unable to distinguish among various types of employment termination. Without this critical information, discharge cannot function effectively as a signal. Moreover, even to the extent that prospective employers can discover at least the sequence and duration of prior jobs, frequent job changes are common in early career and in some occupations and industries. ${ }^{96}$ Indeed, without more detailed information about the reason for each job movement, prospective employers might well run the risk of misconstruing the meaning of the signal. ${ }^{97}$

Thus we see that each of the potentially beneficial effects of discharge on labor market efficiency may be undermined by incomplete or asymmetric information, and that churning may result. Unfortunately, there is no natural market mechanism to eliminate churning. As noted earlier, individual employers benefit from the ability to discharge undesirable employees even though all employers collectively suffer from the resulting degradation of the quality of the pool of job seekers. However, the possible signaling function of discharge suggests a strategy by which employers might try to avoid the ill effects of churning. Employers could conceivably protect themselves against hiring churned employees by refusing to hire anyone who has been formerly employed elsewhere. In essence, they would infer from a change in jobs that someone is more likely to be an undesirable employee. Adopting such a strategy essentially creates a closed internal la-

\footnotetext{
${ }^{9}$ For example, the turnover rate in the health care industry is distinctly higher than that of the manufacturing sector. The annual turnover rate in the health care industry during 1994 and 1995 was 15.6 percent, whereas the annual turnover rate in the manufacturing sector during the same time period was only 9.6 percent. Turnover rates also vary with company size. Companies with between 250 and 499 employees experienced the highest turnover rate in 1994, averaging 13.2 percent, while companies with more than 2,500 employees had only a 9.6 percent turnover rate, BNA's Quarterly Report on Job Absence and Turnover-4th Quarter 1995, 47 Bulletin to Management BNA Policy and Practice Series (Mar 14, 1996); BNA's Job Absence and Turnover Report-4th Quarter 1994, 46 Bulletin to Management, BNA Policy and Practice Series 76-77 (Mar 9, 1995).

${ }^{97}$ I analyze this possibility more fully in the next section's discussion of scarring.
} 
bor market..$^{98}$ The available empirical evidence shows that such firms are exceedingly rare. ${ }^{99}$ However, many employers undoubtedly follow less extreme versions of this signaling strategy. In certain circumstances, or for some jobs, they rely on signals about prior employment history to sort prospective employees. Unfortunately, this common strategy creates the potential for scarring, the third inefficiency resulting from employee turnover.

\section{Scarring.}

Scarring occurs when employers rely on labor market signals, such as prior employment history or employment references, to deny a job to someone who could be profitably employed. Consider again our example of the lecherous science teacher. Suppose that we know the allegations of sexual misconduct are true and that rather than providing a misleadingly positive letter of reference, the school discloses only his job title and dates of service. Schools to which the teacher applies may react in two general ways to this situation. First, schools might ignore the lack of a reference and evaluate the teacher on the basis of other available evidence such as his academic record, professional certifications, personal references, and interview performance. Churning is a likely result. On the other hand, schools might worry that the lack of a reference is a signal of misconduct. They may therefore refuse to hire the discharged teacher or any other candidate who does not have adequate references from all former employers. ${ }^{100}$ This use of labor market signals creates the possibility of scarring.

See, for example, Michael L. Wachter and Randall D. Wright, The Economics of Internal Labor Markets, 29 Industrial Relations 240 (1990); George A. Akerlof and Janet L. Yellen, eds, Efficiency Wage Models of the Labor Market (Cambridge 1986).

${ }^{\rightarrow}$ See John Thomas Delaney, David Lewin, and Casey Ichniowski, Human Resource Policies and Practices in American Firms 12-15 (Dept of Labor 1989). It is impossible for many employers to maintain ranks of employees who would be available to fill any possible job opening at higher levels. Smaller employers, for example, often have several discrete groups of workers with no shared skills or natural lines of progression from entrylevel to higher positions. An employer's need for employees at various levels also may fluctuate unpredictably. A closed internal labor market cannot easily adjust to such demand fluctuations. Finally, filling a higher-level vacancy can cause a cascade of vacancies in various subordinate positions and therefore require many promotions and transfers to fill all of the affected positions. Hiring an outsider to fill a position allows an employer to avoid training and transition costs for the large number of reassignments that purely internal promotion requires. It is thus fairly easy to understand why the vast majority of employers are unable to establish completely closed internal labor markets.

${ }^{100}$ Recall that precisely this fear motivated some legislatures to adopt service letter statutes around the turn of the century. See notes $29-34$ and accompanying text. 
Without the benefit of employment references, prospective employers cannot distinguish voluntary from involuntary terminations. Moreover, the fact that some of those who voluntarily terminate their employment may be doing so under the threat of discharge undermines the potential value of drawing such a distinction. ${ }^{101}$ Employers may respond to this uncertainty by assuming that anyone without a reference would have received a negative one and therefore refusing to hire both those who quit and those who are discharged. But this rule for disqualifying job applicants is overinclusive. Indiscriminately denying employment to all those who have experienced an employment termination requires employers to shun many potentially productive candidates. A substantial portion of disqualified candidates will have quit for personal reasons that do not reflect badly on their productivity. ${ }^{102}$ Moreover, a number of those discharged for poor performance will have been unsuccessful because of a firm-specific factor, such as a personality conflict or bad luck, that again implies nothing about their general productivity. A potentially significant social cost of incomplete and asymmetric information is, therefore, the greater difficulty that these individuals may have finding appropriate employment.

Scarring also can occur when prospective employers receive negative information from former employers about the reasons for termination. They may, for example, learn that a job candidate was discharged from his last job and receive a statement of

${ }^{101}$ See, for example, Former Assistant DA Files Suit Over His Firing for Sexual Encounter, 1996 Daily Labor Rep 141, d1I (July 23, 1996) (discussing Lee $v$ City and County of San Francisco, No C-96-2505 (N D Cal, July 12, 1996), in which an employer told plaintiff to resign or be fired); Fuentes $v$ United Parcel Service, 1996 Daily Labor Rep 121, d4 (June 24, 1996) (LEXIS) ("In return for a severance package, [two managers] were allowed to resign for 'personal reasons' on the condition that they sign releases waiving any employment discrimination claims arising from the employment terminations."); Stuempges $v$ Parke, Davis \& Co, 297 NW2d 252, 255 (Minn 1980) (Employee was promised a positive reference in exchange for resigning voluntarily.).

${ }^{102}$ Indeed, available statistics on employee turnover suggest that the majority of employment terminations are voluntary quits. See Michael A. Campion, Meaning and Measurement of Turnover: Comparison of Alternative Measures and Recommendations for Research, 76 J Applied Psych 199, 204 (1991). This study found that between 70.2 and 76.3 percent of employee terminations were voluntary. Between 23.6 and 33.5 percent of turnover was due to "personal reasons" (attending school, personal factors, moving away, health). Other leading reasons included: higher wages/career opportunity (between 24.1 and 30.7 percent); lack of promotion (between 1.1 and 6.7 percent); dissatisfaction with work schedule (between 0.4 and 2.2 percent); dissatisfaction with work conditions (between 0.4 and 7.6 percent); and dissatisfaction with supervision (between 0.4 and 9.5 percent). See also, Job Absence and Turnover Control, BNA Personnel Policies Forum Survey No 132, 13-15 (October 1981). It is important, however, to bear in mind the inherent limitations of these self-reported data. We have no independent means of verifying that the subjects accurately classified their reasons for employment termination. 
reasons for the firing. If the stated reasons cast doubt on the candidate's productivity, many prospective employers can be expected to rely on these signals to deny him a job. But the employers' decision rule is once again potentially overinclusive. Sometimes the stated reasons for termination will be factually true but incomplete. Thus, prospective employers may not learn about additional exculpatory facts or subjective contextual evidence that would dispel the inference of low productivity. Sometimes the stated reasons may be untrue. False reports of misconduct or incompetence can interfere with the employment prospects of even highly productive individuals. Although it is rational for employers to rely on this information, the resulting hiring decisions may nevertheless leave productive workers unemployed or underemployed. ${ }^{103}$

In an ideal world, of course, prospective employers would be able to rely on a full and candid disclosure from an applicant's former employers to decide whether the reasons for a particular employment termination disqualify him or her from consideration for a job. The problems of mismatching, churning, and scarring cannot occur in a full-information equilibrium. We know, however, that such disclosure rarely occurs. ${ }^{104}$ The question that I consider in the remainder of this Article is whether there are effective regulatory solutions to these problems or whether they are perhaps best left to the natural corrective mechanisms of the market.

\section{Pursuing a Full-Information Equilibrium}

I have shown that incomplete and asymmetric information about employee productivity can cause three labor market inefficiencies. It is therefore natural to consider whether legal regulation or spontaneous market processes could solve these problems. Two types of governmental intervention could, in theory, achieve

${ }^{103}$ The problem of scarring is somewhat similar to statistical discrimination on the basis of race or gender. See, for example, Stewart Schwab, Is Statistical Discrimination Efficient?, 76 Am Econ Rev 228 (1986); Shelly J. Lundberg and Richard Startz, Private Discrimination and Social Intervention in Competitive Labor Markets, 73 Am Econ Rev 340 (1983); Edmund S. Phelps, The Statistical Theory of Racism and Sexism, $62 \mathrm{Am}$ Econ Rev 659 (1972). Scarring is undoubtedly inefficient as compared to an equilibrium in which information is costless, but once we acknowledge that employers must expend real resources to acquire information about job candidates, the argument for inefficiency is more tenuous. Relying on signals is a time-honored way to economize on information costs. Thus, we should not conclude that scarring is necessarily inefficient unless we can identify a costeffective way to provide better information about applicants or unless employers have a socially excessive incentive to rely on these labor market signals.

${ }^{104}$ See notes 66-68 and accompanying text. 
first-best efficiency. Under one approach, regulators would impose a disclosure obligation designed to move the labor market toward an efficient full-information equilibrium. An alternative approach would involve subsidies and penalties designed to influence primary conduct such as hiring, firing, and quitting. However, the inherent complexity of administering these schemes presents an insurmountable practical barrier to their implementation. Potential market solutions would encounter significant coordination problems in addition to the problem of verifiability that makes disclosure regulations ineffective. Thus, I conclude that a first-best equilibrium is unachievable.

\section{Disclosure regulations.}

Mismatching, churning, and scarring arise from incomplete and asymmetric information about productivity. A logical regulatory response to these problems therefore would be to require employers to disclose everything that they know about their former employees. At least in theory, such a full disclosure obligation would eliminate the informational asymmetry between former and prospective employers and could provide more complete information to be used in hiring and other employment decisions. As a practical matter, however, such a full disclosure requirement would be impossible to administer.

Third party judicial decisionmakers would have to determine whether or not an employer had made a full and truthful disclosure. However, we have seen that inherently unverifiable subjective assessments of productivity play a significant role in evaluating employees. ${ }^{105}$ Any feasible disclosure rule would have no effect on the disclosure of this information because it is quite simply impossible to enforce legal rules that make liability contingent on unverifiable information. ${ }^{106}$ Moreover, enforcement costs would be extremely high. Employers and their agents often make no permanent record of even objectively verifiable facts about employees. As a result, regulators or aggrieved parties trying to discover whether a former employer had failed to disclose important information would have to depose every supervisory employee who might have observed something significant. Finally, the sheer number of regulated transactions would be several or-

\footnotetext{
${ }^{105}$ See note 69 and accompanying text.

${ }^{106}$ Compare Alan Schwartz, Relational Contracts in the Court: An Analysis of Incomplete Agreements and Judicial Strategies, 21 J Legal Stud 271, 280-83 (1992) (explaining that contract terms based on unobservable or unverifiable terms are unenforceable because courts adopt a passive approach in such cases rather than base their decisions on speculation).
} 
ders of magnitude greater than the number governed by existing disclosure schemes. ${ }^{107}$

Both the difficulty of verifying that disclosure had been made and the burden of enforcement costs inevitably would make any real-world disclosure scheme incomplete. ${ }^{108}$ Somewhat ironically, such incomplete disclosure may be worse than none at all. Partial disclosure of negative information increases the risk of scarring. Prospective employers who learn some facts about job candidates' prior misconduct may shun those workers even though they would have been eligible for hiring if the employers either knew everything or knew nothing about the misconduct. Thus, for example, a manager's subordinate may complain that he demanded sexual favors in exchange for promotion. But suppose that after making a subjective assessment of the complainant's credibility, the employer believes that the complaint is unfounded. ${ }^{109} \mathrm{~A}$ legal disclosure requirement could easily induce the employer to disclose the objectively verifiable harassment complaint. However, prospective employers are far less likely to learn about the former employer's subjective credibility assessment. If employers know only the unadorned fact that a formal sexual harassment complaint named the manager as an offending party, then he may have tremendous difficulty finding a comparable new job.

\footnotetext{
${ }^{107}$ For example, the prospectus requirement for newly issued securities involves a significantly smaller number of transactions per year. Each year, publicly held companies make well over ten thousand new security issues (1994: 17,714; 1995: 22,014) (figures derived from LEXIS prospectuses database). In contrast, the average annual number of job openings filled each year exceeds 20 million. See Bureau of Labor Statistics, Occupational Projections and Training Data 4 tbl 1 (May 1994).

${ }^{106}$ The ideal of a full-information equilibrium also requires individually determined wages. If there are constraints on wage bargains, then even a full-information equilibrium could leave less desirable workers underemployed. One fairly robust stylized fact about current labor markets is that wages are most often linked to jobs rather than negotiated on an individual basis. Workers then compete for the most desirable positions. One consequence of this market structure is that wages tend to be somewhat inflexible within job categories. Employers presumably set wages at a level equal to the average marginal product of employees in the category. This wage structure gives employers an incentive to discharge workers who underperform the level of productivity that employers might hope to obtain from a new hire. Moreover, if the information available to employers about each employee's productivity is anything less than complete, then offering or accepting a lower than normal wage could be a damning signal of low productivity. Because of adverse selection, such contracts might be impossible to sustain, and the no-contract equilibrium could prevail. Compare Rothschild and Stiglitz, 90 Q J Econ 629, 629 (cited in note 72). Finally, even to the extent that it is possible to control the flow of information available to prospective employers, firms would still be free to use their private information in inefficient ways. Firms would make discharge decisions based in part on unverifiable subjective assessments of productivity. It might often be the case, however, that such discharges would produce churning.

${ }^{109}$ The employer may have noted internal inconsistencies in the complainant's story or may be aware of a history of filing unfounded harassment complaints.
} 


\section{Behavioral regulations.}

Rather than trying to control the flow of information about former employees, regulators could instead design rules that would influence primary conduct such as hiring, firing, and quitting. Existing doctrines such as respondeat superior and the torts of negligent hiring and negligent retention take this approach. Employers are strictly liable for employee torts committed within the scope of employment; in addition, they face negligence liability for their employees' misdeeds whenever they could have taken cost-effective precautions to prevent harm. ${ }^{110}$ This liability exposure theoretically forces employers to make efficient decisions about hiring, assigning, and retaining employees who may cause harm to others.

As my analysis of churning demonstrated, however, employers have socially excessive incentives to discharge undesirable workers. ${ }^{111}$ Courts determined to prevent inefficient churning would have to supplement existing law with additional causes of action. ${ }^{112}$ First, an employer would have to be held liable for "negligent discharge" whenever churning occurred. Similarly, workers would have to be liable for "negligent quitting" whenever they voluntarily terminated their employment in order to move inefficiently between two jobs.

A moment's reflection on the complex considerations that determine whether turnover inefficiently churns employees or instead promotes socially beneficial matching, deterrence, incapacitation, or signaling should make it obvious that no administrable legal rule could consistently draw the necessary distinctions. ${ }^{113}$ Moreover, adequate disclosure by the former employer might sometimes prevent churning. Thus, a negligent discharge tort would require courts to assess the accuracy and completeness of any information that the discharging employer provided to prospective employers. All of the administrative difficulties that afflict disclosure regulations thus apply with equal force to the be-

\footnotetext{
${ }^{110}$ I reviewed these doctrines at length in an earlier work. See J. Hoult Verkerke, Notice Liability in Employment Discrimination Law, 81 Va L Rev 273 (1995).

"See text accompanying note 93.

${ }^{112}$ Another less plausible alternative would be to develop a centrally managed system of assigning workers to jobs. Although this approach is used by private employers in some corners of the labor market, see for example, Alvin E. Roth, The Evolution of the Labor Market for Medical Interns and Residents: A Case Study in Game Theory, $92 \mathrm{~J}$ Pol Econ 991, 996-97 (1984) (discussing medical intern assignment program), its usefulness as a model for the labor market as a whole seems quite doubtful.

${ }^{113}$ See Section II.B.2. It would be especially difficult to determine who should be liable when employers and workers conceal disciplinary discharges as voluntary terminations. See note 101.
} 
havioral alternative. Finally, the negligent quitting tort would somehow have to take account of worker preferences. Subjective and idiosyncratic reactions to different workplaces could quite easily make one of two ostensibly identical jobs far more desirable than the other. Workers thus might always attempt to avoid liability by representing that some intangible personal factor makes the new job a much better match than the prior one. We may fairly conclude that behavioral regulations are no more likely than disclosure obligations to achieve first-best efficiency.

\section{Market solutions.}

Although one might hope that market actors seeking profitable business opportunities will develop market mechanisms for providing an optimal supply of reference information, several problems make that happy outcome exceedingly unlikely. First, employers themselves - or informational intermediaries acting on their behalf - face the difficult problem of making a market for information. They must define the allocation of liability risks among the parties, determine how to value each unit of information, and develop methods for disseminating the information. In addition, they face the general problem of innovating in an uncertain legal environment. Potential reference entrepreneurs might well have to develop new contractual terms to govern their relationship with both the suppliers and the ultimate consumers of reference information. ${ }^{114}$ The fact that many contractual innovations exhibit the characteristics of a public good diminishes somewhat the incentive to invest heavily to overcome these barriers.

But, of course, the genius of the free-market system is that it often creates significant rewards for the first company to solve these problems. Assuming that some intrepid entrepreneur ultimately could overcome these obstacles, she then would confront exactly the same problem of verifiability that bedevils any attempt to establish comprehensive disclosure regulations. Market actors cannot contract on the basis of unverifiable information any more than regulators can compel its disclosure. Thus, even if market participants are able to overcome coordination problems, the inherently unverifiable character of much significant information will prevent the market from attaining a full-information

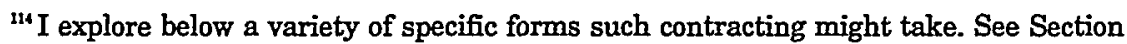
III.D. For our present purposes, it suffices to show that the market is no more likely than disclosure regulations to produce a first-best efficient equilibrium. 
equilibrium. Hence market mechanisms, like government intervention, will be unable to attain first-best efficiency. ${ }^{115}$

This Section has shown that neither informational nor behavioral regulations have any realistic prospect of achieving firstbest efficiency. Inevitably incomplete and prohibitively costly to enforce, comprehensive disclosure requirements are doomed to failure. Any attempt to design tort rules to provide efficient incentives for employee turnover seems no more likely to succeed. Finally, market efforts to exchange information confront difficult coordination problems in addition to the problem of verifiability that constrains the effectiveness of disclosure regulations.

\section{REGULATING EMPLOYMENT REFERENCE PRACTICES}

We have observed the theoretical difficulties of designing legal rules to combat mismatching, churning, and scarring. In this Section, I apply these insights to better understand why the regulatory response to the problems of employment references has been so modest. The framework I have developed provides a positive explanation for this regulatory reticence. In addition, by identifying the most severe losses resulting from inadequate reference information, the framework indicates which types of limited legal reforms have the greatest chance of improving labor market efficiency. However, other significant social values limit the political feasibility of some of these potentially efficiencyenhancing measures.

\section{A. Falsely Negative References and the Persistence of Defamation Liability}

By far the most prominent and pervasive form of legal regulation affecting employment reference practices is defamation law. In every American jurisdiction, the tort of defamation imposes liability on employers who provide falsely negative references. ${ }^{116}$ This uniformity surely arises in part out of sympathy for the victims of defamatory references. A single bad reference often is enough to prevent someone from getting a job for which he is otherwise qualified. ${ }^{117}$ Thus, falsely negative reference informa-

${ }^{115}$ This conclusion is undoubtedly no surprise to students of the literature on the economics of information. See, for example, Sanford J. Grossman and Joseph E. Stiglitz, On the Impossibility of Informationally Efficient Markets, 70 Am Econ Rev 393, 404 (1980) (demonstrating that the price system informs market participants only imperfectly about the fundamental values of securities, thus leaving some returns to arbitrageurs who invest in discovering nonpublic information).

${ }^{116}$ See notes 14-19 and accompanying text.

${ }^{117}$ See, for example, Anderson $v$ Vanden Dorpel, 268 IIl App 3d 907, 645 NE2d 250, 253 
tion not only imposes a significant loss on individual workers; it also causes the labor market inefficiency that I have called scarring. ${ }^{118}$

But in order to understand the remarkably uniform legal response to this problem, we also must consider what causes employers to provide falsely negative references. Although employers themselves may sometimes have a malicious desire to sabotage a former employee's career, defamatory references more commonly occur when one of an employer's supervisory agents develops a dislike for a particular employee. ${ }^{119}$ In this classic agency problem, the supervisor's desire to satisfy a malicious motive conflicts directly with the employer's interest in treating both current and former employees fairly. But if straightforward agency costs produce most defamatory references, it is fair to ask whether the problem requires legal regulation at all.

The answer to this question lies in a close examination of employers' incentives to control their agents. It is only former employees and their prospective employers who experience any direct harm from inaccurate references. In the absence of legal regulation, one thus might expect employers to take very few precautions to ensure the accuracy of the reference information that they provide. But even without defamation liability, two market mechanisms could theoretically provide the necessary incentives. First, an employer might develop a reputation among employers for providing falsely negative information. Such a reputation presumably would lead other employers to ignore negative references received from that employer. But this hypothetical sanction creates at most a trivial incentive for taking precautions against false references because employers generally do not care whether other employers pay attention to the references that they provide. ${ }^{120}$ Moreover, no obvious mechanism exists for disseminating the information that would establish an employer's reputation for providing falsely negative references. Employers typically do not

(1994), revd, 172 Ill 2d 399, 667 NE2d 1296 (1996) (Prospective employer was enthusiastic and supportive until it received a negative reference from defendant, at which point it decided not to hire plaintiff.); Sigal Construction Corp $v$ Stanbury, 586 A2d 1204, 1207 (DC 1991) (Plaintiff was offered a job subject to approval by the owner of a project who received an unfavorable reference concerning plaintiff and refused to approve his hiring.).

${ }^{118}$ See Section II.B.3.

${ }^{\mathrm{n}}$ See, for example, Pavilon v Kaferly, $204 \mathrm{Ill}$ App 3d 235, $149 \mathrm{IIl}$ Dec 549, 561 NE2d 1245,1247 (1990) (Plaintiff was discharged and allegedly defamed after she ended a romantic relationship with her supervisor.).

${ }^{120}$ But see Paetzold and Willborn, 30 Am Bus L J 123, 126 (cited in note 19) (offering creative arguments for why employers should care; but acknowledging that employers presently seem not to see much value in providing accurate references). 
share with other employers information about the accuracy of references that they receive. ${ }^{121} \mathrm{Few}$ prospective employers seek references repeatedly from the same past employers. Even more tellingly, employers often simply refuse to hire job candidates who receive a negative reference. Thus, they never have an opportunity to learn whether the negative reference is false.

Nevertheless, a second market mechanism could theoretically encourage accurate references. An employer might develop a reputation among workers for falsely condemning former employees. Such a reputation might, like bad working conditions or arbitrary discipline, require the employer to pay a compensating wage differential to attract and retain qualified workers. This higher wage cost would provide a powerful incentive for the employer to take precautions against providing falsely negative references. But workers are even less likely than prospective employers to be able to determine whether any particular employer deserves such a reputation. Employment references are provided in confidence to employers, and they ordinarily concern former employees. Thus, neither current nor prospective employees can realistically hope to learn whether or not an employer provides accurate references. ${ }^{122}$ Without this information, a reputation among workers simply cannot form.

The ineffectiveness of reputation as an incentive device, and the absence of any other plausible market check, suggests that at the least courts should impose liability on employers for providing falsely negative references and require an express waiver to overcome this presumptive assignment of liability. ${ }^{123}$ Under such

${ }^{21}$ Employers have a proprietary interest in the information they have gathered, and such disclosure carries with it some risk of legal liability for excessive publication or for defaming the referring employer. One exception to the general rule of nondisclosure is the occasional discussion concerning reference accuracy in the community of legal academics. Some providers of academic references have become notorious for offering glowing recommendations in support of even rather mediocre candidates. Such empty praise is routinely discounted. Perhaps because negative recommendations are comparatively rare, I am aware of no similar example in which a community of employers discounts negative information.

${ }^{12}$ Indeed, the only plausible source of such information would be complaints from former employees who thought that they had been falsely condemned in a reference. The sporadic nature of such complaints, coupled with a lack of first-hand information about the content of the reference, makes me profoundly skeptical that complaints are a realistic basis for forming the necessary reputation.

${ }^{123}$ Although a contractual default rule assigning this risk to the employer might achieve roughly the same purpose, traditional limitations on contract damages, including certainty and foreseeability, would make the expected recovery undercompensatory. Tort damages are somewhat more generous and protect more completely the employee's proprietary interest in his reputation. In the text, I also explain why courts might be skeptical that contractual terms varying this assignment of liability were the product of an effi- 
a rule, employees could agree prospectively to waive their right to recover for defamatory references. However, the same barriers to obtaining information about employers' reference practices that prevent reputation from functioning as an effective incentive device also cast doubt on the wisdom of permitting parties to contract out of liability for providing falsely negative references. Employees have no access to reliable information about reference practices and therefore cannot assess the risk of defamatory references. Because of this informational asymmetry, employers might demand and employees might agree to a prospective waiver of defamation liability. Employers thus could externalize the costs of falsely negative references. Without defamation liability, former employees and prospective employers bear the burden for such references. ${ }^{124}$ As a result, we should expect employers who demand and receive a prospective waiver to take inefficiently few precautions against providing falsely negative references. Labor market efficiency thus provides a justification for imposing non-waivable liability in these circumstances. ${ }^{125}$

The analysis in this Section has shown that falsely negative references produce an externality that burdens former employees and causes scarring. Because the labor market cannot easily transmit information about employers' reference practices-either among other employers or among workers-defamation law is a logical regulatory response to this externality. This analysis thus provides a positive explanation for the prominence and per-

cient bargaining process.

${ }^{124}$ It may be instructive to compare reference practices to the terms governing discharge under indefinite term employment contracts. Because an arbitrary and unjust discharge costs the employer a productive employee and often harms internal morale, employers have substantial incentives to control their supervisory agents. See J. Hoult Verkerke, An Empirical Perspective on Indefinite Term Employment Contracts: Resolving the Just Cause Debate, 1995 Wis L Rev 837 (offering both empirical and theoretical arguments in support of the prevailing default rule of employment at will). In contrast, falsely negative references affect only former employees and prospective employers. I also have shown that no effective reputational or other market checks force employers to take care against providing inaccurate references. In particular, employees are far more likely to know the circumstances surrounding a coworker's discharge than they will be to know whether their employer is making defamatory statements about former employees. This lack of extralegal incentives provides both a positive explanation and a normative justification for adopting a more aggressive regulatory approach to defamation and employment references than to indefinite term employment contracts.

${ }^{125} \mathrm{~A}$ student commentator has suggested permitting parties to contract within certain limits for modifications of the liability standard for defamation. See Horkan, Note, $79 \mathrm{Va} \mathrm{L}$ Rev at 526 (cited in note 3). The limits he suggests are generally compatible with my analysis and leave the employer facing some significant threat of liability. Id at 520, 547. Horkan rejects the possibility of allowing employees to execute a complete waiver of defamation liability. Id at 547. For additional discussion of these and other contractual devices, see Section III.D. 
sistence of the tort of defamation. ${ }^{126}$ It also offers a normative reason to resist any proposals to eviscerate defamation liability. ${ }^{127}$

\section{B. Activity-Level Problems and Possible Solutions}

\section{The role of the common interest privilege.}

Although we have seen that defamation law is necessary, an unwelcome side effect of imposing liability for falsely negative references is a reduction in the total quantity of references provided. The deterrent effects of liability thus improve reference quality, but at the expense of a lower activity level. ${ }^{128}$ In other areas of tort law, courts have imposed strict liability precisely to produce such decreases in activity level. ${ }^{229}$ In regulating employment reference practices, however, lawmakers appear to believe that providing reference information is a socially valuable activ-

${ }^{126}$ As I have already observed, an action for defamatory references is available in every American jurisdiction. No other feature of employment reference regulation enjoys such uniform acceptance.

${ }^{127}$ Some of the more vigorous critics of defamation law impliedly suggest eliminating its application to employment reference practices except in cases of knowing falsity. See, for example, Reed and Henkel, 26 Am Bus L J at 323 (cited in note 3); Brian McCall, Employers Need To Know Job Histories, Dallas Morning News 13A (Nov 13, 1995). Other critics have made more modest proposals to clarify existing law. See, for example, Saxton, 13 Yale L \& Policy Rev at 113 (cited in note 1) (proposing that the malice standard be discontinued and defamation liability be found for: (1) knowing or reckless falsity; (2) false publication beyond the privilege; or (3) disclosure of defamatory matter not reasonably related to the purpose of the privilege). Such doctrinal clarification could well help defamation law to perform its deterrent function more effectively. Reducing uncertainty tends to reduce enforcement costs and to facilitate the efficient negotiation and settlement of legal disputes. But there is little reason to believe that clarification would produce a significant increase in employers' willingness to share information.

I am also skeptical that any doctrinal innovation can substantially lessen the factual uncertainty at the heart of defamation law. The truth or falsity of the challenged statement and the employer's level of fault will always be contested issues of fact. Nevertheless, defamation doctrine is admittedly more ossified and arcane than many other areas of tort law. Doctrinal clarification might reduce uncertainty about liability and thus reduce somewhat the disincentive to providing candid references. Recent codifications of the conditional privilege can be understood as legislative efforts to encourage courts to clarify the contours of the privilege as it applies to employment references. See notes $60-62$ and accompanying text.

${ }^{128}$ This conclusion is a commonplace observation in the economic analysis of tort law. See, for example, Steven Shavell, Economic Analysis of Accident Law 21-32 (Harvard 1990).

${ }^{122}$ George Priest has recounted the influence of this activity-level rationale on modern tort law. See generally George L. Priest, The Invention of Enterprise Liability: A Critical History of the Intellectual Foundations of Modern Tort Law, $14 \mathrm{~J}$ Legal Stud 461 (1985). Steven Croley and Jon Hanson are presently the most ardent academic advocates of the activity-level analysis of strict products liability. See Steven P. Croley and Jon D. Hanson, Rescuing the Revolution: The Revived Case for Enterprise Liability, 91 Mich L Rev 683, 797 (1993). 
ity that should not be unduly discouraged. ${ }^{130}$ Accordingly, existing law incorporates the conditional "common interest" privilege. The conditional privilege raises the standard of proof for defamation plaintiffs when they challenge statements, such as employment references, that are made between parties who have a common interest in knowing the information. ${ }^{131}$ In theory at least, this partial protection from suit encourages employers to provide information in precisely those circumstances where it is most valuable. ${ }^{132}$ Those who make falsely negative statements outside of these specially valuable circumstances must defend any resulting defamation claims on less favorable legal ground.

At this point, however, a legal economist might well ask why we should not simply impose strict liability for defamatory statements and rely on the market to determine the optimal quantity of information to be provided. ${ }^{133}$ Two factors militate against this approach. First, although in theory the choice between strict liability and negligence has no effect on precautions, it will ordinarily affect activity levels. ${ }^{134}$ It is plausible to assume that imposing strict defamation liability on employers would lead them to provide fewer references than they would provide if negligence or some other more protective fault standard applied.

Second, and perhaps more significantly, markets for information are generally somewhat fragile. ${ }^{135}$ The market for reference information, in particular, must confront a number of difficulties such as establishing the value of each reference, collecting and disseminating references in a timely fashion, verifying the accuracy of the provided information, and finally determining the allocation of legal liability associated with sharing reference information. Whether or not market participants can surmount such

${ }^{130}$ See note 60 and accompanying text.

${ }^{131}$ See notes $23-26$ and accompanying text.

${ }^{132}$ The common interest privilege confers special protection on statements when a sufficiently substantial social interest in the free flow of information is at stake. Although it is an admittedly crude distinction, the limited application of the privilege is entirely consistent with the quantity-quality trade-off. Increasing the quantity of references provided is most likely to be worth the cost of more falsely negative references (a decline in quality) in those situations singled out by the common interest doctrine. The quest for a common interest identifies those situations in which the challenged statement has a social value beyond the intrinsic pleasure of communication. It is this added social value that justifies conferring special legal protection on privileged statements.

${ }^{133}$ Indeed, at the time of Blackstone, defamation was a strict liability tort. After a period of evolution, however, a fault requirement has become firmly established in defamation doctrine. For a detailed historical discussion of defamation law, see Lewis, Ottley, and Mersol, 54 Mo L Rev at 802-09 (cited in note 3).

${ }^{134}$ See note 128.

${ }^{135}$ See Section III.D (discussing a variety of barriers to creating a market for reference information). 
problems, the existence of these barriers to a thriving market for references helps to explain why a lawmaker might be inclined to reject strict liability for defamation in favor of an approach that relies less heavily on market incentives to ensure an adequate supply of reference information.

The unavoidable trade-off between the quantity and quality of information thus has led courts, and an increasing number of state legislatures, to give employers who provide references the protection of a conditional privilege. ${ }^{136}$ But if a little bit of privilege is good, one might ask, why not provide more? Lawmakers could presumably generate an even greater quantity of references by conferring on employers an absolute privilege similar to the protection afforded statements made in judicial proceedings. ${ }^{137}$ An absolute privilege, however, would be ill-advised for essentially the same reason that defamation law has remained prominent in the legal regulation of employment reference practices. Defamation liability deters employers from ignoring the costs they impose on former employees when they provide falsely negative reference information.

Moreover, the doctrinal rule conferring an absolute privilege for judicial testimony cleverly selects a situation in which alternative constraints on quality provide an adequate substitute for defamation liability. Someone who testifies falsely faces an (admittedly remote) possibility of perjury prosecution. More significantly, testimony is offered in an adversarial setting. The opposing party typically has both an ample opportunity and a substantial interest in refuting any false statement, even if only to impeach the credibility of a hostile witness. ${ }^{138}$ Finally, most statements in litigation reach a restricted audience of individuals-the judge, jury, lawyers, and the litigants themselves-who, outside of the litigation outcome, have no particular control over the subject's future. In contrast, prospective employers determine

${ }^{136}$ As I explained earlier, the legislative efforts appear to do little more than codify the preexisting common law conditional privilege. It remains to be seen whether these legislative "good faith" privileges will be more protective than the common law variety. See notes 60-62 and accompanying text.

${ }^{137}$ See Restatement (Second) of Torts $\$ \S 587-88$ (granting an absolute privilege for parties and witnesses to judicial proceedings). Several states have extended the absolute privilege to administrative proceedings. See, for example, Blote $v$ First Federal Savings \& Loan Association of Rapid City, 422 NW2d 834, 838 (SD 1988).

${ }^{133}$ The Fair Credit Reporting Act's procedures for correcting inaccuracies in investigative consumer reports similarly might provide a check on the accuracy of employment reference information contained in those reports. 15 USC $\$ \S 1681$ et seq (1994). The need for defamation liability is reduced precisely to the extent that independent mechanisms for ensuring accuracy are effective. I discuss this possible role of FCRA-like procedures below. See Section III.D. 
whether a person will be gainfully employed or instead remain unemployed. Employment references thus differ significantly from judicial testimony in ways that make an expansion of the absolute privilege exceedingly unlikely. ${ }^{139}$

Although strong arguments support lawmakers' consistent rejection of the extremes of strict liability and absolute privilege, determining the proper intermediate level for the privilege depends on assessing the likely effects of different levels of protection. Because of empirical uncertainty about these effects, it is possible that anything from a negligence standard to a rule requiring proof of actual malice could be the optimal legal standard that properly balances the quantity and quality of reference information. This uncertainty explains the variety of standards we observe. ${ }^{140}$ Without concrete empirical evidence, however, lawmakers should be skeptical of reform proposals that would shift the quantum of proof required to show an abuse of the conditional privilege. Both anecdotal accounts and survey evidence demonstrate that employers presently provide a substantial amount of information about former employees. ${ }^{141}$ And yet complaints about an inadequate supply of certain types of reference information persist. The conditional privilege undoubtedly encourages some employers to provide references. But no available evidence shows that substantially increasing or decreasing the burden of proof on defamation plaintiffs would generate a better balance between the quantity and quality of reference information available to prospective employers. Thus, although the optimal degree of protection is uncertain, the central role of the conditional privilege in defamation law appears secure.

\footnotetext{
${ }^{139}$ Another possible explanation for the absolute privilege in judicial proceedings is that witnesses can be compelled to testify against their will. On this theory, it would be unfair to expose someone to defamation liability for making negative statements under the threat of a contempt sanction. In my view, this explanation fails because it also would predict that such witnesses would be made immune from perjury prosecution. The fact that no immunity protects them from criminal liability for false statements suggests that the compulsion cannot explain witnesses' absolute immunity from civil liability for those same false statements.

${ }^{140}$ See Horkan, Note, $79 \mathrm{Va} \mathrm{L}$ Rev at 523-26 (cited in note 3) (discussing jurisdictional variations in standards for abuse of the privilege).

" For example, one recent survey found that for nine out of eleven categories of information, less than half of employers reported that they received an "inadequate" amount of information from employment references. See SHRM Survey (cited in note 2). No empirical work is available to demonstrate that strict liability would not produce the same quantity of information. But employers' lobbying efforts in favor of bills that would codify, or strengthen slightly, the conditional privilege supports the belief that such protections influence their behavior.
} 
2. Disclosure obligations: an ineffectual solution to the activity-level problem.

Nevertheless, an extensive literature asserts that, despite the conditional privilege, defamation law deters employers from providing an adequate quantity of references. ${ }^{142} \mathrm{~A}$ direct regulatory strategy for overcoming this activity-level problem would be to mandate disclosure. Although we already have seen that a fullinformation equilibrium is unattainable, ${ }^{143}$ even a limited disclosure obligation might force former employers to be more forthcoming. Unfortunately, the potential benefits of a disclosure obligation are outweighed by the difficulty of enforcement, the costs associated with partial disclosure, and the possibility of strategically motivated litigation.

As I have observed already, no enforceable legal rule can compel employers to disclose unverifiable subjective assessments of employee productivity. ${ }^{144}$ Employers might even adapt to a disclosure obligation by making more observations of employees practically unverifiable in order to avoid potential liability. They might, for example, prepare and retain fewer documentary records of employee misconduct. The practical value of a disclosure duty thus is strictly limited by these enforcement difficulties. Moreover, I have noted that partial disclosure can be worse than no disclosure at all. ${ }^{145}$ Employers can be compelled to disclose verifiable facts-a sexual harassment complaint or an accidentbut not subjective assessments of responsibility and credibility. Even innocent employees could be scarred and thus condemned to chronic unemployment or underemployment by such incomplete disclosures.

A final difficulty with disclosure obligations is that they create opportunities for wasteful strategic litigation. Whenever an employee engages in serious misconduct, his former employers could be dragged into a legal battle over who is responsible. A cause of action for failure to disclose would encourage plaintiffs to investigate each and every prior employer of the tortfeasor for any evidence that those former employers had notice of the injurer's dangerous proclivities. A modest increase in the available quantity of information may not be worth the additional cost and complexity of deciding whether the former employer in fact had notice of the employee's propensity to engage in misconduct. Un-

\footnotetext{
${ }^{142}$ See note 2.

${ }^{143}$ See Section II.C.

${ }^{14}$ See Section II.C.I.

${ }^{1 * 5}$ See Section II.B.3.
} 
less the scope of the duty to disclose is unmistakably clear and unambiguous, former employers could well be forced either to defend the reasonableness of their disclosure decisions or to pay settlements to avoid the cost of litigation. Given the potentially amorphous quality of information about risks, the opportunity for exploitative strike suits is substantial. These considerations help to explain why lawmakers generally have chosen not to impose such disclosure obligations on employers. ${ }^{146}$

\section{Special considerations for high-risk occupations.}

Although generally applicable disclosure obligations seem unpromising, the analysis of the relationship between churning and severe mismatching shows that increasing the quantity of available information about the reasons for discharge would be especially valuable to employers hiring workers for high-risk occupations. A more targeted regulatory approach might therefore mandate specific, verifiable disclosure and reporting obligations for such occupations. Thus, for example, drug and alcohol test records for truck drivers, train engineers, and pilots might be made available to all prospective employers. The necessary reporting obligations could conceivably be incorporated into the existing licensing and health certification procedures that exist for these occupations. ${ }^{147}$ Similarly, employers of school teachers might be required to report complaints of inappropriate behavior to the public agency that issues teaching certifications.

As we have seen, however, a countervailing risk of disclosure obligations is an increase in the incidence of scarring. ${ }^{148}$ To be sure, in these high-risk contexts we should be willing to tolerate adverse decisions made on the basis of less certain information about a worker's propensity to commit harm than we would require in normal-risk employment. ${ }^{149}$ However, even targeted disclosure obligations could create a risk of wasteful, strategically motivated litigation. ${ }^{150}$ Only by relying exclusively on administrative enforcement mechanisms could regulators avoid this risk. ${ }^{151}$

${ }^{146} \mathrm{My}$ review of state law suggests that only three states have service letter statutes backed by a significant enforcement mechanism. See note 33. Even in these states, I am aware of no study systematically assessing the effectiveness of these disclosure obligations.

${ }^{147}$ See, for example, 14 CFR §§ 61.1-67.31 (1997) (establishing requirements for certification of flight crew members for proficiency and health).

${ }^{148}$ See Section II.C.1.

${ }^{14}$ See Frederick Schauer and Richard Zeckhauser, On the Degree of Confidence for Adverse Decisions, 25 J Legal Stud 27, 31 (1996).

${ }^{250}$ See note 146 and accompanying text.

${ }^{131}$ For this reason, we might expect to see expanded reporting obligations first in in- 
Perhaps a more significant constraint on imposing reporting and disclosure regulations is the uniquely powerful fear that most Americans have of centralized data gathering. ${ }^{152}$ This visceral reaction against the machinations of Big Brother and his private siblings is an important political obstacle to the adoption of any reporting scheme. These political constraints coupled with the risk of scarring suggest that only quite narrow reporting obligations are likely to be imposed.

Given these barriers to the adoption of a comprehensive reporting and disclosure scheme for high-risk occupations, we should consider alternative policies. Existing law relies heavily on negligence rules to impose duties of prehiring investigation, thorough training and supervision, and prompt response to signals of trouble. Reform-minded judges could strengthen these duties, requiring high-risk employers to undertake all cost-effective means of inducing former employers to reveal information about job candidates. ${ }^{153}$ This approach diminishes the risk of strategic litigation because only the employer responsible for hiring and supervising the employee-tortfeasor would face potential liability. ${ }^{154}$ Moreover, an especially stringent formulation of the duty to investigate might encourage employers to develop innovative market-based solutions to the informational problem. I consider below whether other complementary legal reforms could facilitate the development of these market mechanisms.

As we have seen, many commentators lament the fact that the threat of defamation liability deters not only falsely negative references but also valuable truthful references. They propose a variety of reforms to deal with this problem. ${ }^{155}$ The framework shows how complex interactions in the labor market make an assessment of such proposals exceptionally difficult. In short, there

dustries such as transportation where existing licensing procedures provide a ready administrative enforcement mechanism.

${ }^{152}$ For an often fascinating exploration of the role of privacy and the uses of information in modern technological society, see Oscar H. Gandy, Jr., The Panoptic Sort: A Political Economy of Personal Information ch 5-6 (Westview 1993).

${ }^{153}$ These duties could also require employers to seek information from public agencies or even private informational intermediaries whenever the nature of the job warranted those additional inquiries.

${ }^{154}$ Under present law, a vicarious liability action almost always will lie against the employer of a worker who commits a tort related in any way to his or her employment. Such a regime in which there is but one potential defendant for each employee tort contrasts sharply with a mandatory disclosure regime under which all prior employers also face the possibility of a lawsuit for failing to disclose information about the employee's dangerous proclivities. See note 146 and accompanying text.

${ }^{155}$ See sources cited in note 3 . A number of commentators also propose clarifying existing defamation law, to which I have no real objection, but I doubt that such clarification will change employers' behavior significantly. 
is no a priori basis on which to assess whether the gains from more information sharing would outweigh the costs of a greater number of falsely negative references and the potentially harmful effects of partial disclosure. Nevertheless, the analysis of mismatching and churning demonstrates that lawmakers are most likely to create new disclosure obligations for high-risk occupations. Such efforts to prevent severe mismatching would be especially valuable. But if the necessary data-gathering so offends privacy norms that it is politically infeasible, then stringent negligent hiring liability might be sufficient to encourage high-risk employers to use creative means of uncovering the necessary information.

\section{Falsely Positive References and the Shortcomings of Wrongful Referral Liability}

As we have seen, activity-level problems are one unwelcome side effect of defamation liability. However, the focus of defamation law on negative references also encourages employers to provide positive references, sometimes even falsely positive references. This Section considers whether firms should be held liable for wrongful referral when they materially misrepresent a former employee's productivity.

Although the fear of defamation liability may often deter them from providing any references at all, employers are essentially immune from suit if they provide only positive references. ${ }^{156}$ From a manager's perspective, a requirement that all references be positive is more difficult to administer than a clear but crude policy that strictly limits reference disclosures to job title and dates of service. After all, the more restrictive policy relieves managers from the onerous duty of monitoring all communications to ensure that no negative remarks find their way into otherwise innocuous references. Nevertheless, a positive reference strategy is among the set of plausible employer responses to the

\footnotetext{
${ }^{156}$ In theory, an employer that provided only positive references might be held liable for defamation whenever it chose to remain silent about a former employee. The employee would argue that prospective employers had inferred from the absence of a reference that her performance was inadequate. Courts have occasionally found such silence actionable when a discharge occurred in particularly incriminating circumstances. See Berg $v$ Consolidated Freightways, Inc, 280 Pa Super 495, 421 A2d 831, 835 (1980) (affirming judgment in slander suit for employee fired in the midst of a criminal investigation of workplace theft); Tyler $v$ Macks Stores of South Carolina, 275 SC 456, 272 SE2d 633, 634 (1980) (finding that the trial court correctly denied demurrer on a defamation claim made by a former employee fired after a polygraph test). My research has, however, uncovered no case in which plaintiff's claim rested solely on a selective positive reference policy.
} 
threat of defamation liability. ${ }^{157}$ Moreover, the analysis of churning demonstrates that employers sometimes have an affirmative incentive to provide falsely positive references in order to unload undesirable employees on the labor market. ${ }^{158}$ In addition, the potential liability to discharged employees under various statutory and common law theories of wrongful discharge sometimes leads employers to agree to provide an undeserved positive reference in exchange for the employee's voluntary resignation. ${ }^{159}$ Finally, reemployment terminates an employer's liability for unemployment compensation and provides a pecuniary reason for firms to help their former employees secure new positions. There is thus an ample incentive to provide positive references.

Moreover, as my analysis of the problem of falsely negative references demonstrated, there is no effective market check on providing inaccurate reference information. ${ }^{160}$ Indeed, falsely positive references burden only prospective employers. Former employees themselves undoubtedly welcome the chance to rely on false praise. As a result, one of the two possible reputational checks on providing false information cannot possibly deter falsely positive references. ${ }^{161}$ In fact, an employer might even develop a favorable reputation among employees for routinely giving positive evaluations. This skewed incentive structure thus seems likely to produce a significant number of falsely positive references.

Surprisingly modest extensions of existing legal theories would be sufficient to hold employers liable for the consequences of providing falsely positive references. First, the regulatory principle underlying defamation law is that employers must be deterred from providing false reference information that harms former employees. This basic principle could quite readily be extended to include falsely positive information that causes pro-

${ }^{157}$ Indeed, the SHRM Survey results suggest that many employers may have adopted this approach. SHRM Survey (cited in note 2) (finding that disclosure is seemingly more likely for positive or neutral information than for unambiguously negative information such as "violent/bizarre behavior").

${ }^{15 s}$ See Section II.B.2.

${ }^{159}$ See note 101. A study of patterns in discrimination litigation also suggests that the risk of discrimination suits is greatest when discharged employees remain unemployed for a longer period of time. See John J. Donohue, III and Peter Siegelman, Law and Macroeconomics: Employment Discrimination Litigation Over the Business Cycle, $66 \mathrm{~S}$ Cal L Rev 709, 722 (1993). Employers seeking to avoid litigation thus would find it in their interest to help such former employees find new jobs.

${ }^{100}$ See Section III.A.

${ }^{161}$ See notes 120-22 and accompanying text (discussing how the possibility of developing a reputation among workers for providing falsely negative references could provide an incentive to take precautions to ensure the accuracy of references). 
spective employers and third parties to suffer injury as a result of severe mismatching. Second, the contract doctrine of misrepresentation recognizes the inefficiency that results when one party exploits its informational advantage to deceive another party about the desirability of an exchange transaction. ${ }^{162}$ The recipient of a falsely positive reference often will be induced to form a contract with a job applicant in reliance on the accuracy of the reference. Admittedly, the reference ordinarily comes from one who has no contractual relationship with the recipient, but the potential for inefficiency is every bit as great as when the misrepresentation comes directly from a contractual partner. Finally, the tort of fraudulent inducement is stated in sufficiently broad doctrinal terms that it readily could be extended to cover falsely positive references. ${ }^{163} \mathrm{~A}$ court would have to find only that the relationship between a former employer and the recipient of an employment reference was sufficiently special to warrant imposing a duty of accuracy on the former employer. ${ }^{164}$

Despite these convenient doctrinal precedents for wrongful referral liability, few courts have even considered the theory, and there has been no rush to embrace it legislatively. Although lawmakers' lack of interest may seem somewhat puzzling, a variety of practical problems make this theoretically plausible doctrinal innovation unlikely to occur. First, wrongful referral liability has the potential to shut off the flow of reference information completely. The danger of excessively deterring truthful referencegiving is particularly acute because an employer can avoid potential liability only by providing no references whatsoever or by disclosing only such limited information that no suit can possibly arise for wrongful referral. ${ }^{165}$ While defamation law undoubtedly deters some employers from providing even truthfully negative references, an action for wrongful referral also might prevent

${ }^{162}$ See note 36 and accompanying text.

${ }^{100}$ See Restatement (Second) of Torts $\$ 537$ ("Whe recipient of a fraudulent misrepresentation can recover against its maker for pecuniary loss resulting from it if, but only if, (a) he relies on the misrepresentation in acting or refraining from action, and (b) his reliance is justifiable."). Nondisclosure or partial disclosure is similarly actionable in some circumstances. See Restatement (Second) of Torts $\$ 551$. See also Restatement (Second) of Torts $\$ \S 310-11$ (Intentional and negligent misrepresentations are actionable in cases in which reliance on the misrepresentations results in physical harm.).

${ }^{164}$ The few courts to have considered this theory are sharply divided. See notes 37-38 and accompanying text. Compare Tarasoff, 551 P2d at 348 (holding that psychotherapist whose patient presents serious danger of violence to another has a duty to use reasonable care to protect intended victim by steps that may include warning of the threat).

${ }^{168} \mathrm{~A}$ common strategy is to disclose only a former employee's job title and dates of service. See note 65 and accompanying text. The odds of misrepresenting this information are presumably quite low. 
employers from signaling their level of satisfaction with former employees by providing positive references with different degrees of enthusiasm. ${ }^{166}$ Prospective employers use this signal to identify unusually good candidates even though it is considerably more difficult to discover negative information. Indeed, the available empirical evidence suggests that although the current regulatory regime chills negative disclosures, it also permits a considerable quantity of positive information to flow. ${ }^{167}$

Because the line between falsely positive statements and the omission of material negative information is as arbitrary as the distinction between action and inaction, ${ }^{168}$ wrongful referral must necessarily become, at least in part, a legal disclosure obligation. ${ }^{169}$ Enforcement problems similar to those that afflict conventional disclosure obligations thus would inevitably diminish the usefulness of the wrongful referral theory. Plaintiffs would face the difficult and expensive task of proving prior knowledge on the part of a former employer. Liability would perversely encourage employers to make relevant information more difficult to verify. Anyone injured by an employee tort would have a strategic reason to name former employers as codefendants whenever a facially colorable factual basis exists for asserting that the former employer may have known the employee had a propensity to commit such acts. ${ }^{170}$ Finally, the possibility of intervening negligence on the part of the current employer, who controls the work

${ }^{166}$ In markets like legal academics, job candidates generally select their own references. The track record of the person giving the reference and the degree of enthusiasm with which the reference describes the candidate sometimes allow the recipient to distill a reasonably accurate signal from the reference.

${ }^{167}$ See SHRM Survey (cited in note 2).

${ }^{168}$ For examples of work criticizing this distinction, see Arthur Allen Leff, The Leff Dictionary of the Law: A Fragment, 94 Yale L J 1855, 1913-14 (1985) (discussing the concept of "active cause"); Cass R. Sunstein, Reviewing Agency Inaction After Heckler v Chaney, 52 U Chi L Rev 653, 683 (1985) (arguing that "inaction' is itself a decision" and applauding the trend in judicial review treating action and inaction similarly).

${ }^{169}$ See, for example, Randi W. $v$ Muroc Joint Unified School District, 14 Cal 4th 1066, 929 P2d 582, 593 (1997) (finding misrepresentation liability for failing to disclose complaints of sexual misconduct in the course of providing highly positive recommendation letters). Compare Restatement (Second) of Contracts § 161 (extending the doctrine of misrepresentation to some forms of nondisclosure).

${ }^{170}$ Although defamation law also creates a risk of strategically motivated and unfounded litigation, the marginal increase in the number of suits employers must defend is less than it would be under a wrongful referral theory. Most employment reference defamation claims are brought in conjunction with statutory discrimination or common law wrongful discharge actions. See note 19. Because these claims would be brought anyway, defamation law produces more additional claims than additional suits. In contrast, the threat of wrongful referral liability would force former employers to defend lawsuits in entirely new factual situations for which they presently have no legal exposure whatsoever. 
environment and determines job assignments, would significantly cloud the issue of causation.

These problems make me profoundly skeptical that many jurisdictions will decide to impose general wrongful referral liability. As in the case of targeted disclosure obligations, however, the benefit from deterring falsely positive references would be greatest for high-risk occupations. Indeed, the California Supreme Court's ruling in Randi W. $v$ Muroc Joint Unified School District ${ }^{171}$ can be understood as establishing a duty narrowly tailored to the high-risk circumstances in which a "substantial" risk of physical harm is "foreseeable." These doctrinal requirements give the court ample flexibility to restrict this new duty to the situations that I have described here as high-risk employment. Imposing a narrowly tailored obligation to disclose accurately and completely significant risk factors could reduce the incidence of churning and severe mismatching. Moreover, the framework shows that it is for high-risk occupations that we should be most willing to accept the danger of scarring and excessive deterrence that these new duties entail. Lawmakers could choose either a tort of wrongful referral or an administrative reporting scheme to enforce employers' new obligations. Because wrongful referral liability relies on third party, rather than administrative, enforcement, it creates greater risks of strategic litigation. However, a wrongful referral tort would create fewer concerns about privacy because it lacks any centralized data collection mechanism. Thus, reformers might succeed in promoting either a limited administrative reporting scheme or a wrongful referral tort focused on readily identifiable high-risk occupations.

\section{Market Mechanisms for Information Sharing}

The preceding three Sections have shown why lawmakers might be reluctant to alter the existing regulatory scheme for employment reference practices. Dramatically expanding the privilege could increase the quantity of references provided, but at the expense of eliminating employers' only significant incentive to take care against providing falsely negative references. Enforcement costs and potentially perverse effects such as scarring and strategic litigation also explain why disclosure obligations and a tort of wrongful referral have attracted so little judicial or legislative support. It remains in this Section to consider how the legal regime affects several important market mecha- 
nisms for producing and sharing information about prospective employees. ${ }^{172}$

Informational intermediaries such as private investigation services, executive search consultants, and headhunters are the principal actors in the market for reference information. ${ }^{173}$ These intermediaries each operate on a distinctive business model, but a common characteristic of their activities is that they provide to employers information about job applicants in exchange for monetary compensation. The intermediaries themselves and their sources of information are subject to the strictures of defamation law. Nevertheless, the available evidence, although fragmentary and anecdotal, suggests that there is a thriving market for their services. ${ }^{174}$ These market transactions demonstrate not only that the information they provide is valuable but, perhaps more significantly, that the current law of defamation is not so draconian that it chills all useful communications about prospective employees.

Despite the evident success of these informational intermediaries, one type of transaction is conspicuously absent from the market. Neither employers nor intermediaries pay other employers to reveal information about former employees. Employers may be uncertain about each party's legal responsibilities and therefore find such a transaction unattractive. But defamation liability is insurable, ${ }^{175}$ and thus the parties should expect a court to enforce almost any indemnification agreement or assignment of liability that they might devise. ${ }^{176}$

\footnotetext{
${ }^{172}$ As I have observed already, employers sometimes attempt to contract out of defamation liability. The legal effect of prospective waivers and of an employee's consent to obtain references is uncertain. See notes $45-47$ and accompanying text. Use of these contractual devices to create the equivalent of an absolute privilege undermines the incentive effects of defamation liability and therefore creates a substantial risk of scarring. In this Section, I focus instead on alternative market mechanisms that preserve defamation liability and therefore provide greater protection against scarring.

${ }^{173}$ See, for example, William T. Hill, Getting Help from the Outside, Security Management 15A (July 1, 1990) (discussing nationwide private investigation agencies and the newest technological tools used for preemployment screening); Angela Ahn, Headhunters Battle Second Class Image, Houston Chron 9 (July 20, 1986) (reporting that there are more than 1,500 executive search firms in business today with over half of those established in the past twenty years).

${ }^{174}$ See, for example, Bob Smith, Pinkerton Keeps Its Eye on Recruitment, HR Focus 1, 6 (Sept 1993) (discussing an investigation company that screens more than one million job applicants annually).

${ }^{175}$ See, for example, Ruder \& Finn, Inc $v$ Seaboard Surety Co, 52 NY2d 663, 439 NYS2d 858, 422 NE2d 518, 521 (1981) (enforcing policy providing express coverage for defamation actions).

${ }^{176}$ I am referring here to contracts allocating liability between the referring employer, an informational intermediary, and the ultimate recipient of reference information. We saw earlier that, in several jurisdictions, a contract for a prospective waiver of defamation
} 
A more likely explanation for the absence of such payments is the difficulty that the parties would have determining how to price the information. A flat rate for each reference would have to be low enough to make the purchase worthwhile even though, in the majority of cases, the former employer will have nothing valuable to disclose. If the price per reference is therefore quite low, employers who know particularly damaging information will be disinclined to expose themselves to potential defamation liability in return for such a trivial sum. ${ }^{177}$ Any attempt to tie compensation to the value of the information disclosed, however, creates a perverse incentive for former employers to manufacture negative information in order to earn these larger payments. Although defamation liability undoubtedly constrains this tendency, the fear of such strategic behavior surely might dissuade a prospective employer or informational intermediary from making a variable payment offer. As a result, one striking characteristic of reference information may be that it is only valuable when the original source of that information has given it away for free.

Although individual reference-for-payment transactions do not occur, an ongoing reciprocal arrangement to exchange reference information with other employers or with an informational intermediary would not violate this principle of free disclosure. One employer might agree with other local employers to provide candid assessments of former employees who apply to work for those other employers. In return, the other employers would disclose similar information about their former employees. ${ }^{178}$ Since each disclosure depends only on an employer's expectations of future reciprocal exchanges, rather than on the marginal fee payable for that individual reference, the problems associated with variable payment would not distort the employer's incentive to disclose. Employers also could hope that the value of the ongoing exchange would be sufficient to overcome the problem of nondisclosure that afflicts a flat-fee payment scheme. After hiring a job

liability is void as contrary to public policy. See note 47 and accompanying text. This judicial resistance to contractual devices that extinguish a victim's right to sue for defamation does not appear to extend to contracts allocating the financial burden of defamation liability among third parties.

${ }^{17}$ From the perspective of a referring employer, receiving a small payment in exchange for particularly negative information is virtually indistinguishable from providing the information for free. A flat-fee payment scheme could include a contractual duty to disclose all relevant information. As we have seen, however, problems of verifiability and strategic litigation make such disclosure obligations costly to enforce. See text accompanying notes 69-70.

${ }^{178}$ See, for example, Charles R. McConnell, How Dangerous Is the Truth in Employment References? 12 Health Care Superv 1, $11-12$ (1993) (noting that hospital personnel departments often share reference information in the health care industry). 
applicant, the recipient of a reference ordinarily would discover a former employer's failure to disclose negative information. Presumably, too many incidents of nondisclosure would cause the recipient to terminate the reciprocal relationship. ${ }^{179}$

Of course, this technique for obtaining information only works when a group of employers can expect a reasonably continuous exchange of references. An informational intermediary, however, may be able to overcome this limitation by contracting with a larger number of employers and using its own investment in reputation to bond the accuracy of the references it provides. The intermediary conceivably could charge a flat fee for all references. The intermediary's desire to maintain a market reputation for full disclosure might be sufficient to prevent it from withholding negative information in order to avoid the risk of defamation liability.

Regrettably, other problems make the ultimate success of such a venture somewhat doubtful. Although the intermediary's reputational stake in accuracy is clear, inadequate incentives exist to ensure that the sources of reference information-referring employers-will disclose significant negative information. First, a referring employer must retain liability for defamatory references in order to maintain its incentive to avoid providing falsely negative references. ${ }^{180}$ But the risk of defamation liability creates an incentive for the referring employer to withhold negative information. The only sanction with which the intermediary can penalize falsely negative or incomplete disclosure is to sever its relationship with the referring employer. Unless this relationship is quite valuable, the sanction will be ineffective. Indeed, if there are alternative intermediaries with whom the employer could contract in the future, then the threat of termination almost certainly cannot ensure complete disclosure.

Even if a more meaningful sanction were available, the mechanism by which the intermediary could hope to learn of incomplete disclosures would be indirect and unreliable. The ulti-

\footnotetext{
${ }^{179}$ However, the inference of nondisclosure would be quite uncertain. Without conducting a detailed investigation of an employee's prior conduct, an employer cannot know whether the employee's former employer has observed behavior that manifested a propensity for misconduct. As my description of experience traits made clear, a prior employer might well be ignorant of such significant traits as recklessness or a tendency to violence. See text accompanying notes 66-68.

${ }^{150}$ If the intermediary agreed to assume the risk of defamation liability, the referring employer would be in the enviable position of receiving whatever benefits flow from providing references and bearing none of the costs. The intermediary's only available sanction for falsely negative references would be to sever its relationship with the offending employer.
} 
mate recipient of the reference information would have to discover the incompleteness and inform the intermediary that the disclosure was inadequate. The intermediary would then have to determine whether the recipient's complaint or the referring employer's denial was more credible. Even more tellingly, recipients of potentially incomplete references might simply decide not to do business with the intermediary again, never explaining the cause of their dissatisfaction. Intermediaries could not realistically hope to decode such indistinct signals and hold referring employers responsible for the resulting loss of business. ${ }^{181}$

These obstacles to market transactions are most easily overcome when the stakes are high. Indeed, employers hiring for jobs at the "high end" of the labor market-positions in the upper levels of management, for example-appear to use informational intermediaries quite extensively. ${ }^{182}$ The evident success of the market for high-value reference information suggests that it is worth considering whether legal regulation could perhaps facilitate market devices for producing and sharing useful information in the rest of the labor market. In short, is there any chance that reference information for ordinary jobs will become a widely traded commodity?

The limitations we have just considered impede intermediaries' efforts to extend the routine exchange of information beyond the narrow reciprocal setting of small groups of employers. Nevertheless, many third party investigative services presently conduct routine reference checks and investigate job applicants on a fee-for-service basis. ${ }^{183}$ These private investigators realize economies of scale and develop special skills for discovering relevant information. ${ }^{184}$ Investigative services thus trade on their

\footnotetext{
${ }^{181}$ Intermediaries also would have to cope with a significant timing problem. It would be difficult for them to ensure that they had current information about each job applicant for whom employers would seek references. One way of dealing with this problem might be to conduct an investigation and collect information on demand. This approach creates the potential for substantial delay and resembles quite closely the sort of investigative effort that the employer might easily undertake by itself. As I discuss below, however, a thriving market exists for investigation on demand. Thus, it appears that these timing problems alone would not prevent a broader market for reference information from succeeding.

${ }^{102}$ Although the market for reference information thrives at the high end of the labor market, I have discovered no evidence that original sources receive payment for their disclosures.

${ }^{183}$ See notes 173-74 and accompanying text.

${ }^{14}$ For example, they develop expertise in obtaining access to and an understanding of useful computer databases. They also gain experience that may show them how best to approach former employers to induce them to part with information. Finally, they discover who else to ask for relevant information (neighbors or local merchants, for example).
} 
specialization of labor to displace or supplement pre-employment investigations that employers could perform themselves.

The FCRA supplements the common law of defamation as it applies to the "investigative consumer reports" that these services prepare. ${ }^{185}$ However, because Congress designed the FCRA principally to correct flaws in the operation of the market for credit information, ${ }^{186}$ its provisions are best adapted to regulate information of that type. First, the FCRA provides several procedural protections to "consumers," including notice that an investigative report will be prepared, notice of an adverse decision based on information in a report, and an opportunity to challenge the accuracy of information contained in a report. ${ }^{187}$ These requirements prevent lenders from denying credit on the basis of secret information and give consumers a fair opportunity to correct errors in their credit record. ${ }^{188}$ To encourage potential sources of credit information to divulge what they know, the FCRA also codifies a conditional privilege for all participants in the credit reporting process. ${ }^{189}$ This conditional privilege appears to be sufficient to induce creditors to disclose the necessary information to credit reporting bureaus.

One important explanation for the continued vitality of the credit reporting industry is the fact that credit information is objective and verifiable. ${ }^{190}$ In contrast, employment references normally include subjective performance assessments. Any negative judgments contained in those references necessarily imply the

${ }^{185}$ See 15 USC $\S \S 1681$ et seq (1994). See also text accompanying notes 50-54.

${ }^{186}$ The FCRA's section containing "[c]ongressional findings and statement of purpose" begins with the finding that, " $[t]$ he banking system is dependent upon fair and accurate credit reporting. Inaccurate credit reports directly impair the efficiency of the banking system, and unfair credit reporting methods undermine the public confidence which is essential to the continued functioning of the banking system." 15 USC $\S 1681(a)(1)$. Tellingly, there are no analogous findings concerning the use of consumer reports for employment purposes. Instead, the statute refers to "other information on consumers" and to "personnel, insurance, and other information" almost as an afterthought. See 15 USC $\S 1681(\mathrm{a})(3),(\mathrm{b})$.

${ }^{187}$ See 15 USC \$§ 1681i, 1681k, 1681m.

${ }^{188}$ See 15 USC $\S 1681(b)$ (emphasizing adoption of procedures "fair and equitable to the consumer").

${ }^{18} 15$ USC § 1681h(e) (1994).

${ }^{200} \mathrm{~A}$ creditor who discloses a debtor's payment history is unlikely to make a mistake, and it will be extremely difficult to prove that any mistake was willful or malicious. See id. For normal credit information, the most common problem is almost certainly inadvertent clerical errors in reporting. A conditional privilege provides predictable protection against the threat of defamation liability in these circumstances. Providers of credit information also are far less likely than employers to have the sort of personal relationship with delinquent debtors that could provide a factual basis for alleging malice or a willful intent to injure. Comparatively anonymous creditors are thus far more likely to find the protection of the conditional privilege entirely adequate. 
existence of potentially defamatory facts. ${ }^{191}$ Moreover, the underlying observations that support employers' performance appraisals are often far more difficult to verify than a debtor's payment history. In order to defend the truth of their negative judgments, employers must testify about employee shortcomings such as inept or lackadaisical job performance, insubordinate comments or behavior, and the amorphous problem of a "bad attitude." Evidence that is so inherently fluid and indefinite can never be sufficient to prevail on summary judgment and often leaves an employer uncertain about the likely outcome at trial. Thus, perhaps employment reference reporting bureaus have not arisen because of this comparatively greater exposure to defamation liability. The increased threat of suit for defamation prevents employers from sharing what they know about former employees as freely as banks and other creditors share information about their customers. Indeed, it is hard to imagine an employer uttering the threat: "Improve your performance or we will report you to the employment reference reporting bureau," even though creditors routinely issue analogous threats to delinquent creditors.

Lawmakers concerned about this problem could consider amending the FCRA to confer an absolute privilege on those who provide employment references. Such complete protection against the threat of defamation liability presumably would encourage employers to supply a larger quantity of candid reference information. As we have seen, however, defamation law is necessary to force employers to consider the costs that falsely negative references impose on their former employees. ${ }^{192}$ Nevertheless, we also have seen that the availability of alternative devices for combating the ill effects of falsely negative references can sometimes justify an absolute privilege, as it does for statements made in a judicial proceeding. ${ }^{193}$ Lawmakers could expand the existing protections of the FCRA to include a final and binding procedure for resolving disputes about the accuracy of information contained in an investigative report. ${ }^{194}$ Such an amended FCRA would offer former employees protection against falsely negative

${ }^{199}$ See note 16.

${ }^{12}$ See Section III.A.

${ }^{123}$ See text accompanying notes 137-39.

${ }^{19}$ The existing FCRA procedure inadequately protects employees since it permits even potentially inaccurate information to remain in the report with only a summary of the employee's objections to it. See 15 USC \& 1681i. A prospective employer is likely to believe the original source of information rather than a job applicant's self-serving exculpatory statement. 
references roughly comparable to the adversarial setting of judicial proceedings.

Although reforms or new regulatory schemes modeled after the FCRA may warrant further investigation and even some experimentation, two significant objections stand as obstacles to their wide acceptance. First, the costs of resolving disputes over the accuracy of reference information might well overwhelm the value of the information that the system could provide. Only a system that allows employees to resort to an objective third party decisionmaker could hope to provide a sufficient guarantee against falsely negative references. But the ultimate decisionmaker inevitably would confront all of the uncertainties associated with the unverifiable information on which references are customarily based. Another significant problem is that an amended FCRA could be expected to trigger complaints that it encourages employment reference reporting bureaus to intrude on employees' personal privacy. ${ }^{195}$

The rhetorical and political power of the privacy objection suggests that reference reporting bureaus might be feasible if they were carefully limited to high-risk occupations for which the countervailing social interest in full disclosure is most clear. The framework shows that such a targeted approach could combat severe mismatching. Thus, a well articulated regulatory scheme for reference reporting bureaus could generally protect against scarring, while allowing those who have a particular need for information to acquire it. In this sense, the most promising avenues for reform may mimic the successful sectors of the existing market for information by catering to the needs of high-value consumers of information.

\section{CONCLUSION}

It is something of a puzzle that so many commentators have complained that defamation law prevents employers from providing enough candid reference information, and yet lawmakers have shown little inclination to alter fundamentally the existing regulatory scheme. The analytic framework that I have developed in this Article provides a new and more rigorous understanding of the problems that regulators confront in attempting to influence employment reference practices. We have seen that incomplete and asymmetric information causes three interrelated inefficiencies: mismatching, churning, and scarring. These labor market

\footnotetext{
${ }^{195}$ On the peculiar American aversion to centralized data collection, see Gandy, The Panoptic Sort at ch 5-6 (cited in note 152).
} 
problems arise spontaneously from the efforts of employers to maximize the productivity of their labor force and the simultaneous efforts of employees to maximize the satisfaction they derive from employment. Mismatching, churning, and scarring interact with one another in complex ways, and neither regulatory measures nor market forces can produce an efficient full-information equilibrium.

By examining each of the basic problems facing regulators through the lens of this framework, I have generated a number of positive predictions and a corresponding set of normative justifications regarding the shape of legal regulation. Falsely negative references cause scarring, and no market mechanism adequately internalizes the resulting costs to employees. Thus, defamation law serves the important role of ensuring that employers take adequate precautions against providing falsely negative references. The conditional privilege encourages employers to provide a larger quantity of references. However, the framework shows that lawmakers face substantial uncertainty about the extent of protection that optimally balances the quantity and quality of available information. Both disclosure obligations and a tort of wrongful referral create difficult enforcement problems that explain why they have not been adopted more widely. These more aggressive regulatory cures for the activity-level problem and for falsely positive references may well be worse than the disease. Finally, we saw that although a robust market for reference information can likely be maintained in high-value sectors of the labor market, both practical and political constraints would impede regulatory efforts to encourage innovative market mechanisms for supplying reference information to the "low end" of the labor market.

This Article makes three central claims. First, as a matter of positive theory, it explains features of the existing legal regulation of employment reference practices. It also offers an account of why lawmakers have been reluctant to eviscerate defamation liability, to impose disclosure obligations, or to adopt a wrongful referral tort. Second, the analysis provides a normative argument for differentiating the treatment of employees in high-risk occupations, and thus also helps to explain those aspects of existing law that draw such a distinction. Finally, the analysis of market mechanisms for information sharing shows the problems that lawmakers would confront in attempting to help employers develop more efficient means for collecting and disseminating information about prospective employees. Deeply seated aversions 
to centralized data collection also may make such efforts politically unacceptable.

The framework with which I have analyzed employment reference practices also applies more generally to any form of regulation affecting either employee turnover or the acquisition and use of information about employees. For example, disability discrimination law broadly prohibits employers from discriminating against otherwise qualified persons with a disability. ${ }^{196}$ The Americans with Disabilities Act bars employers from inquiring about job applicants' possible disabilities and imposes on employers a duty of reasonable accommodation. ${ }^{197}$ The analysis of mismatching, churning, and scarring provides a useful framework for understanding the function of these legal duties. The duty of reasonable accommodation prevents churning by requiring employers to retain disabled workers in circumstances in which discharge would be unlikely to improve the quality of the match between worker and job. In addition, the prohibition on inquiring about an applicant's possible disability can be interpreted as an effort to prevent scarring because employers might refuse to hire disabled workers on the basis of this imprecise signal. Thus, just as the analytical framework has produced new insights about the legal regulation of employment reference practices, it could bring a new functional perspective to bear on disability discrimination law.

\footnotetext{
${ }^{106}$ See Americans with Disabilities Act, Pub L No 101-536, Title 1 § 102, 104 Stat 331 (1990), codified as amended at 42 USC § 12112(a) (1994) ("No covered entity shall discriminate against a qualified individual with a disability because of the disability of such individual in regard to job application procedures, the hiring, advancement, or discharge of employees, employee compensation, job training, and other terms, conditions, and privileges of employment.").

${ }^{197}$ See 42 USC $\$ \$ 12112(\mathrm{~b})(5)(\mathrm{A}), 12112(\mathrm{~d})(2)(\mathrm{A})$.
} 